\title{
WHY DO SOME SPECIAL ECONOMIC ZONES ATTRACT MORE FIRMS THAN OTHERS? PANEL DATA ANALYSIS OF POLISH SPECIAL ECONOMIC ZONES*
}

\section{Piotr Ciżkowicza (D), Magda Ciżkowicz-Pękałaa, Piotr Pękałaa, Andrzej Rzońca ${ }^{\mathrm{a}}$}

\begin{abstract}
Using a unique firm-level data for Polish Special Economic Zones (SEZ) to estimate a set of panel data models we find that both employment and investment growth in SEZ are driven mainly by labour market characteristics of zone-hosting regions, while other factors (including market access, zone business climate and firms' concentration) play a less important role. Firms choose their locations based on labour availability rather than on labour costs. Moreover, they pay particular attention to availability of low-skilled rather than high-skilled labour. As far as tax incentives are concerned, their predictability matters more for SEZ development than their generosity.
\end{abstract}

Keywords: Special economic zones, regional economic development, economic policy tools, panel data models

JEL Classifications: H25, H32, R30, C21

\section{Introduction}

Location-based investment incentive schemes are used throughout most countries in the form of free trade zones, enterprise zones, export processing zones, etc. The general expectation is that the beneficial conditions granted to businesses via the schemes will incite new investment and lead to growth in economic activity in regions where these tools are in place. At the same time, however, the preferential treatment of selected firms entails fiscal costs accompanied by possible side impacts on regional competitiveness,

* This work was supported by the National Science Centre Poland under Grant DEC-2013/11/B/ HS4/02124.

a Warsaw School of Economics, Warszawa, Poland.

Email: pcizko@sgh.waw.pl (corresponding author), mcizkowicz@gmail.com, p.pekala2@gmail.com, arzonca@sgh.waw.pl 
unemployment, etc. This naturally leads to questions regarding the effectiveness of location-based incentives and factors contributing to differences in their outcomes across regions. Consequently, the problem of effectiveness of SEZ as a policy tool becomes vital. The problem can be divided into two questions:

(i) Why do similar location-based incentives operating in one region attract more firms than in other regions?

(ii) What effects do firms that benefit from the incentives exert on other firms (with no access to the incentives)?

This study focuses on the first research problem, while the second one is addressed in Ciżkowicz et al. (2016).

We use a unique firm-level data for Polish Special Economic Zones (SEZ) aggregated for 253 powiats (i.e., counties; LAU-1, previously NUTS-4 regions) for the period 2003-2015. The data provide an interesting platform to analyse zones' development determinants for (at least) two reasons. Firstly, despite operating within a similar incentive framework, zones differ considerably with respect to investment attracted and jobs created. For example, the SEZ in Zory created almost 10 times as many jobs as the SEZ in Jastrzebie Zdroj, even though both SEZ were established in the same year and are located in neighbouring counties. Secondly, SEZ have undergone a major evolution over their lifespan that has pertained to every aspect of their functioning.

We study two groups of possible determinants of SEZ development. The first group refers to characteristics of SEZ-hosting counties (such as labour market conditions, industrialization level, infrastructure, location). The second one includes SEZ-specific factors (agglomeration and clustering effects, zone operator, maximum and expected level of tax exemption). To identify the most important determinants, we estimate a set of panel models of employment and investment in SEZ-based firms. The models are estimated both on the entire data sample and on subsamples delimited by the quartiles of distributions of explanatory variables in order to reveal potential nonlinearities of their impact on zones' development.

The main findings of the study are the following:

(i) Both employment and investment growth in SEZ is impacted by labour market characteristics of the SEZ-hosting county: it is higher in SEZ located in counties with high labour participation rates and low wage fund (i.e., defined as the product of employment and average wage). This effect is statistically significant and stronger for firms located in SEZ of above-median size. On the other hand, average wage level has no significant impact on SEZ development. We interpret this as an indication that regional labour availability matters more for employment and investment growth in SEZ than labour 
costs. Investors choose zones located in counties with high labour participation rates and, only among them, with the lowest average wages.

(ii) Employment and investment growth of SEZ is higher in zones hosted by counties with available low-skilled labour. The impact is higher for SEZ with the highest average technological advancement and above-median share of foreign capital and SEZ size. In our opinion, it shows that an important factor determining the development of a SEZ is the regional availability of low-skilled labour, not high-skilled labour, as the latter is much more mobile, and therefore its unavailability in the county does not limit the development of companies in the zone.

(iii) Neither the number nor concentration of firms within a zone have a significant impact on employment and investment growth of SEZ-located firms. By contrast, there is some evidence of positive effects of firms' clustering -in terms of both FDI and technological advancement.

(iv) The planned lifetime of the SEZ known in the year $t$ has a positive and statistically significant impact on SEZ development in terms of employment and - for some specifications - investment. On the other hand, the maximum tax exemption level seems not to affect the rate of employment and investment growth of SEZ (its impact is not robust to changes in specifications). We interpret this as an indication that the uncertainty regarding total tax benefits that investors can expect from presence in the zones hinders SEZ development. This is especially true for fast growing SEZ and those that attract technologically advanced FDI. In contrast, differences in generosity of tax incentives across zones and in time have no significant effect on their relative attractiveness.

The results are robust to changes in the estimation methods and modifications to the set of explanatory variables. That said, the results should be considered with caution, at the very least due to estimation issues that are typical of panels with a short time dimension.

The paper makes four main contributions to the literature on this topic:

(i) While there is abundant literature on SEZ development, studies analysing the determinants of SEZ success with the use of econometric tools are still scarce. We seek to fill this gap.

(ii) There is also very limited formal evidence of impact of tax exemptions on SEZ development. To the best of our knowledge, only the World Bank (2017) analyses this issue directly. However, the study covers SEZ functioning in different countries, i.e., with various institutional setups. In contrast, we analyse the impact of tax exemptions within the same setup. We benefit from a "natural experiment" of numerous changes in tax exemptions in Polish SEZ. The changes also provide a unique opportunity for comparing the importance of generosity of tax incentives against their predictability. 
(iii) The paper also contributes to the literature on regional labour market conditions and SEZ performance. Existing studies are mainly based on country-level or sub-regional data. Due to high diversity of economic conditions within each territorial unit, they are unable to catch the heterogeneity of local labour market characteristics. In contrast, we use county-level data (LAU-1 classification), which is best suited for labour market analysis (Ciżkowicz et al., 2016).

(iv) To the best of our knowledge, we are the first to search for nonlinearities in impact of factors attracting investors to SEZ. Studying these nonlinearities not only has an exploratory value, but can also help policy makers in appropriate design of SEZ.

The paper is structured into seven sections. Section 2 presents the literature related to the research problem. Section 3 sketches the most important information on the SEZ scheme in Poland. Section 4 presents the dataset used in the study and conclusions from the initial data inspection. Section 5 comprises the analytical framework and the estimation strategy. Section 6 describes econometric results. Section 7 concludes.

\section{Related Literature}

There is a broad body of literature documenting large differences in SEZ ability to attract investment and create jobs. The differences occur across and within countries, both developing (e.g., Aggarwal, 2006; Farole, 2011; Zeng, 2015) and developed ones (Billings, 2009; Mayer et al., 2012). They have also existed across Polish SEZ (e.g., Cieslewicz, 2009; Trojak and Wiedermann, 2009).

The research into possible drivers of these differences is based mainly on descriptive case studies (see, e.g., Engman et al., 2007; Farole, 2011; Watson, 2001; Zeng, 2015) and not supported by formal econometric analysis, with literally a handful of exceptions (see, in particular, Aggarwal, 2006; World Bank, 2017). The determinants of SEZ development analysed in the literature can be segregated into five groups:

(i) Market access. Although firms in the early types of SEZ (i.e., export processing zones) were required to export all of their production, currently they often sell on both foreign markets and local ones. As a consequence, a firm's decision to locate in a given SEZ may be influenced not only by the proximity of foreign markets, but also by the local market size.

(ii) National and zone business climate. The business climate in a given region/ country is determined by institutional framework quality - e.g., safety of property rights, corruption, quality and transparency of SEZ law. These factors together may in turn influence both risks and opportunities, as well as costs of starting and running a business in a given location. As pointed out by Farole (2011), SEZ are aimed at improving the business environment relative to the rest of the country mainly by offering access 
to high-quality infrastructure and streamlined administrative procedures. Still, the business climate across individual zones in a given country may vary considerably.

(iii) Labour market conditions. The availability and costs of labour have a strong impact on firms' operating margins. Hence, these factors play an important role in both a firm's decision to locate in a given SEZ and the firm's further performance.

(iv) SEZ institutional setup. SEZ vary considerably in terms of objectives of their creation as well as policy tools applied to reach these goals (Aggarwal, 2010). The variation in applied tools pertains to both the types of incentives offered (e.g., tax exemptions, subsidies, trade preferences) and their size, as well as requirements imposed on SEZ-based firms.

(v) Concentration of firms. The number of firms in the zone has two opposite effects on locational decisions of firms and, hence, zone performance. On the one hand, more firms translates into fiercer competition for limited resources and lower profitability of sales. Existing theoretical studies on firms' locational choices suggest that competition intensifies with firms' proximity (Crozet et al., 2004). On the other hand, the rising number of firms operating in similar sectors increases the probability of a subsequent firm locating in the same area. This phenomenon, known as the agglomeration effect, is driven by positive externalities from firms' co-existence, including technological and knowledge spillovers (Head et al., 1999). Clustering may also be beneficial to firms belonging to the same value chain, as their proximity facilitates trade in intermediate goods (Head and Mayer, 2004). If the agglomeration forces outweigh the negative effects of competition, zones with more firms may perform better in terms of attracting investment and creating jobs.

Among the abovementioned factors, business climate (at a national rather than zone level) and market access are found to be especially relevant. In particular, the econometric analysis based on survey data covering three Asian countries conducted by Aggarwal (2006) indicates that SEZ development varies across countries depending mainly on business climate (proxied by quality of governance in zones, including simplicity of administrative procedures, clear operating rules, etc.) and market size, with no significant impact of infrastructure quality and labour costs. When it comes to differences in SEZ development within an individual country, they relate mostly to local market size and proximity of the zone to strategic points such as airports, ports and large cities. The results of simple correlation analysis performed by Farole (2011) are to a large extent in line with Aggarwal's conclusions: the study shows that performance of individual zones correlates mainly with the national investment climate and the size of local markets.

A significant, positive effect of proximity to large markets is also confirmed by the World Bank (2017), which uses panel data tools, and by Schrank (2001). Both Farole (2011) and the World Bank (2017) find no effects of zone business climate. 
As for the impact of SEZ institutional setup on zone performance, the results are mixed. Survey-based analyses suggest that SEZ type and size are important drivers of investors' decisions to locate in a given zone (Rolfe et al., 2004; Aggarwal, 2006). Also, the literature on determinants of international FDI inflows - a predominant type of investment in many SEZ including Polish ones - suggests that the tax rates are taken under consideration by multinational firms while choosing the investment location (see meta-analysis by de Mooij and Enderveen, 2003). Studies on the impact of tax incentives on infra-national investment flows generally do not challenge the positive impact of lower tax rates on investment (e.g., Mayer et al., 2012; Aggarwal, 2006), although some research indicates that this effect is rather weak (e.g., Rathelot and Sillard, 2008; Devereux et al., 2007; Crozet et al., 2004). Considering the impact on employment, while Aggarwal (2006) and Bondonio and Engberg (2000) find no effect of fiscal incentives on regional differences in employment, Duranton et al. (2011) demonstrate opposite results (Table 1).

Table 1: Results of empirical studies regarding impact of specific factors on SEZ performance

\begin{tabular}{|c|c|c|c|}
\hline & Positive & Neutral & Negative \\
\hline $\begin{array}{l}\text { National } \\
\text { business } \\
\text { climate }\end{array}$ & $\begin{array}{l}\text { Aggarwal, 2006; } \\
\text { Farole, } 2011\end{array}$ & - & - \\
\hline $\begin{array}{l}\text { Zone business } \\
\text { climate }\end{array}$ & - & $\begin{array}{l}\text { Farole, 2011; } \\
\text { World Bank, } 2017\end{array}$ & - \\
\hline Market size & $\begin{array}{l}\text { Aggarwal, 2006; } \\
\text { Farole, 2011; } \\
\text { Schrank, 2001; } \\
\text { World Bank, } 2017\end{array}$ & - & - \\
\hline $\begin{array}{l}\text { Infrastucture } \\
\text { quality }\end{array}$ & - & Aggarwal, 2006 & - \\
\hline Labour costs & - & Aggarwal, 2006 & - \\
\hline Tax rate & - & $\begin{array}{l}\text { Employment: } \\
\text { Aggarwal, 2006; } \\
\text { Bondonio and } \\
\text { Engberg, } 2000\end{array}$ & $\begin{array}{l}\text { Investment: Mayer et al., 2012; } \\
\text { Aggarwal, 2006; Rathelot and Sillard, } \\
\text { 2008; Devereux et al., 2007; } \\
\text { Crozet et al., 2004; } \\
\text { employment: Duranton et al., } 2001\end{array}$ \\
\hline $\begin{array}{l}\text { Number } \\
\text { of operating } \\
\text { enterprises }\end{array}$ & $\begin{array}{l}\text { Devereux et al., 2007; } \\
\text { Mayer et al., } 2012\end{array}$ & Aggarwal, 2006 & - \\
\hline
\end{tabular}

Source: the authors 
As regards the impact of firms' concentration on SEZ development, the predominant view is that firms tend to agglomerate, i.e., SEZ with larger numbers of already operating enterprises have a higher chance of attracting subsequent investors. Such a phenomenon is confirmed by Devereux et al. (2007), who analysed effects of policy aimed at attracting investment into underdeveloped regions in the UK. In the same vein, Mayer et al. (2012) show that for French urban enterprise zones - where a big part of zone investments are due to relocation from an area outside the zone but within the same municipality the probability of a firm locating in the zone is higher when the number of enterprises already located in the SEZ relative to the non-SEZ part of the municipality is high. However, some doubt regarding the impact of agglomeration effects on SEZ performance is cast by Aggarwal (2006), who did not find any impact of firms' concentration in the zone on its performance. In this context, it is worth noting that the literature on agglomeration effects suggests that firms' clustering behaviour varies depending on firms' nationality and industry of operation, the position in the value chain as well as the firms' size (e.g., Crozet et al., 2004; Duranton and Puga, 2001).

\section{Special Economic Zones in Poland}

SEZ in Poland are defined as administratively delimited areas in which investors are granted preferential conditions. Other investment incentive schemes also function in Poland ${ }^{1}$. However, the character of tools used by these institutions to encourage investment and the lack of necessary data impede taking them into account in the current analysis.

The Special Economic Zone scheme aims at accelerating the development of selected parts of Poland primarily by creating new jobs, boosting technology development, enhancing the competitiveness of produced goods and promoting exports. The main incentive offered to investors by SEZ is a tax exemption on income earned from the business activities conducted within SEZ. Additionally, investors planning to locate in SEZ are offered fully equipped plots under preferential conditions.

The SEZ designation, and related tax exemptions are granted conditional on investors' declaration to make a certain fixed investment outlay or to increase employment by a certain number.

1 Apart from Special Economic Zones, there are also two other types of location-based investment incentive schemes: (i) industrial and technological parks, and (ii) duty-free zones and warehouses. These are not the subject of this study. These schemes differ from special economic zones in the way they support entrepreneurship, in particular, in the type of incentives used to encourage investment. Tax incentives are used primarily by SEZ while the remaining schemes rely on preferential access to industrial infrastructure and support services or facilitations in international trade. 
The first SEZ in Poland was established in 1995 in Mielec. As of the end of 2015, SEZ formed 14 groupings roughly corresponding to separate regions of Poland (SEZ were present in all 16 voivodeships). It is worth noting that SEZ groupings are administered by separate management bodies, mainly specialized commercial entities, which may result in differences in governance and efficiency in attracting investors. Over the past decade, SEZ have undergone a major evolution pertaining to (i) size and conditionality of tax exemptions granted to SEZ-based firms, (ii) territorial extension of the scheme and (iii) planned lifespan of the scheme.

(i) The value of income tax exemption granted to companies functioning in SEZ is determined as a share of eligible costs: the qualified value of investment outlay or the value of labour costs of new employees incurred over a 2-year horizon. The share of the eligible costs used to calculate the SEZ exemption is fixed for each region at the level of EU maximum intensity of regional aid. Presently, maximum intensities of regional aid range from $15 \%$ to $50 \%$, depending on the region. Over the lifespan of special economic zones in Poland, the regional aid intensities - and as a result, the available tax exemptions - were subject to substantial evolution both within and between regions. It is worth noting that the largest falls in tax exemptions offered by SEZ occurred in large agglomerations and western regions of Poland, which are considered the most developed, while the eastern - less developed - regions experienced high and stable benefits (Table $\mathrm{A}^{2}$ ).

(ii) Initially, in 1995, the overall territory of SEZ had no predefined limit. In 1999, the SEZ area was capped at 6,325 ha. The area available for SEZ was increased in 2004, but qualifying conditions for potential investors were introduced. The limit increased again in 2006 (together with removal of qualifying conditions), in 2008 and in 2015 (Table A2). The subsequent increases in SEZ area limits may have had an impact on expectations regarding the further development of SEZ and - consequently - locational decisions of enterprises.

(iii) The first SEZ, created between 1995 and 1997, were initially set up to last for 20 years. In 2009, the lifespan of all the SEZ was prolonged until 2020, and in 2013 again until 2026. The lifespan of the SEZ is an important factor for zone development, as it determines the cumulative savings from tax exemptions.

2 All figures denoted ' $A$ ' are available in the online appendix. 
All the changes ${ }^{3}$ mentioned above can be considered a natural experiment that provides an opportunity to evaluate the impact of SEZ scheme characteristics on zone performance. In Section 5, we explain how they are introduced into the analysed panel models.

\section{Data and Stylized Facts}

The data used in the analysis come from two main sources:

(i) The firm-level dataset provided by the Ministry of the Economy, comprising annual data on numbers of SEZ-based firms, employment and total investment made by each firm since its inclusion in the zone, each firm's sector of operations and the investor's nationality. The time span covered in the database is 2003-2015. As such, the dataset represents the most detailed source of information on SEZ, with close to 17,000 individual observations. Given the aim of the study, we aggregate firm-level data to county-level data (LAU-1 classification ${ }^{4}$ ).

(ii) Regional macroeconomic data from the Central Statistical Office. The dataset includes variables that describe: (a) local market potential, (b) labour market conditions, (c) corporate sector structure, (d) local infrastructure, and (e) local government finance.

Table 2 contains a detailed description of the data used in the study. Initial inspection of the data provides the following stylized facts:

(i) The SEZ seem to be effective in achieving their main goals as indicated by the significant size of investment they have attracted and employment that has been created in firms operating in SEZ. In 2015, there were 2,177 firms operating in SEZ with total fixed assets worth 109.7 billion PLN and employment of over 320 thousand people. SEZ success is also mirrored in geographic expansion of zones (Figure A3).

(ii) Investment and employment growth in SEZ varied considerably across counties, pointing to significant differences between SEZ in terms of their performance (Figures 1,2). The heterogeneity in terms of attracted investment and created employment may mirror differences in factors, such as market size, as indicated in Section 2.

3 The paper does not analyse impact of latest changes in SEZ functioning, which were adopted in 2018. The "Act on Supporting New Investment" extended the territory on which investors could execute investment projects under preferential conditions to the entire territory of Poland. While receiving tax exemptions is no longer conditioned on settling the business in a particular area of the country, investments are still required to meet certain quantitative and qualitative criteria.

4 As of 2018, there are 380 counties in Poland. Note that in 2013 the Wałbrzych City County was separated from the Wałbrzych County, resulting in creation of two new counties. In order to assure data comparability across the time dimension, we treat these two counties as one. 
Table 2: Definitions of variables

\begin{tabular}{|c|c|c|c|c|}
\hline Variable & $\begin{array}{c}\text { Name } \\
\text { in models }\end{array}$ & Measure & Definition & Source \\
\hline \multicolumn{5}{|c|}{ Local labour market } \\
\hline Average wage & wage_av & $\begin{array}{l}\text { country } \\
\text { average } \\
\text { wage }=1\end{array}$ & $\begin{array}{l}\text { Average wage in the enterprise } \\
\text { sector (companies employing } \\
\text { over } 9 \text { workers) in the county } \\
\text { as a percentage of country average } \\
\text { in a given year }\end{array}$ & Central Statistical Office \\
\hline Wage fund & wage_fund & $\mathrm{mn}$ PLN & $\begin{array}{l}\text { Product of the number of employed } \\
\text { persons and the average wage } \\
\text { in the county }\end{array}$ & $\begin{array}{l}\text { Authors' calculation based } \\
\text { on Central Statistical Office } \\
\text { data }\end{array}$ \\
\hline $\begin{array}{l}\text { Number of economically } \\
\text { active persons }\end{array}$ & active & - & $\begin{array}{l}\text { Number of economically active } \\
\text { persons (consistent with registered } \\
\text { unemployment definition) } \\
\text { in the county }\end{array}$ & $\begin{array}{l}\text { Authors' calculation based } \\
\text { on Central Statistical Office } \\
\text { data }\end{array}$ \\
\hline $\begin{array}{l}\text { Number of unemployed } \\
\text { persons }\end{array}$ & unemployed & - & $\begin{array}{l}\text { Number of persons registered } \\
\text { as unemployed in the county }\end{array}$ & Central Statistical Office \\
\hline $\begin{array}{l}\text { Share of low-skilled among } \\
\text { unemployed persons }\end{array}$ & $\begin{array}{l}\text { unemployed_ } \\
\text { low }\end{array}$ & $\begin{array}{l}\text { total number } \\
\text { of unem- } \\
\text { ployed }=1\end{array}$ & $\begin{array}{l}\text { Share of persons registered } \\
\text { as unemployed with primary } \\
\text { education in the county }\end{array}$ & $\begin{array}{l}\text { Authors' calculation based } \\
\text { on Central Statistical Office } \\
\text { data }\end{array}$ \\
\hline $\begin{array}{l}\text { Number of tertiary } \\
\text { education graduates per } \\
10 \text { thousand inhabitants }\end{array}$ & graduates & - & $\begin{array}{l}\text { Number of tertiary education } \\
\text { graduates in the subregion (NUTS-3) } \\
\text { divided by the number of residents } \\
\text { of the subregion }\end{array}$ & Central Statistical Office \\
\hline \multicolumn{5}{|c|}{ County characteristics } \\
\hline Industrial production & $\begin{array}{l}\text { ind_- } \\
\text { production }\end{array}$ & PLN & $\begin{array}{l}\text { Value of industrial production per } 10 \\
\text { thousand residents of the county }\end{array}$ & Central Statistical Office \\
\hline Road density & roads_density & $\mathrm{km} / \mathrm{km}^{2}$ & Density of roads in the county & Central Statistical Office \\
\hline Foreign border & border & - & $\begin{array}{l}\text { Dummy variable taking value of } 1 \\
\text { if the county shares a border with } \\
\text { a foreign country and } 0 \text { otherwise }\end{array}$ & Authors \\
\hline \multicolumn{5}{|c|}{ SEZ characteristics } \\
\hline SEZ remaining horizon & $\begin{array}{l}\text { remaining } \\
\text { years }\end{array}$ & - & $\begin{array}{l}\text { Number of years the SEZ scheme } \\
\text { was expected to remain in place } \\
\text { in a given year }\end{array}$ & $\begin{array}{l}\text { Applicable regulations } \\
\text { of the Council of Ministers }\end{array}$ \\
\hline Maximum tax exemption & max_exmpt & $\%$ & $\begin{array}{l}\text { Maximum tax exemption related } \\
\text { to the intensity of regional aid } \\
\text { in the county }\end{array}$ & $\begin{array}{l}\text { Applicable regulations } \\
\text { of the Council of Ministers }\end{array}$ \\
\hline $\begin{array}{l}\text { Number of SEZ-based } \\
\text { companies in the county }\end{array}$ & n_SEZ_firms & - & $\begin{array}{l}\text { Number of SEZ-based companies } \\
\text { operating in the county }\end{array}$ & $\begin{array}{l}\text { Authors' calculation based } \\
\text { on Ministry of Economy data }\end{array}$ \\
\hline Share of foreign capital & share_foreign & $\begin{array}{l}\text { total fixed } \\
\text { capital }=1\end{array}$ & $\begin{array}{l}\text { Share of fixed capital in SEZ-based } \\
\text { companies owned by foreign } \\
\text { investors in total fixed capital in SEZ- } \\
\text { based companies in the county }\end{array}$ & $\begin{array}{l}\text { Authors' calculation based } \\
\text { on Ministry of Economy data }\end{array}$ \\
\hline $\begin{array}{l}\text { Technological } \\
\text { advancement }\end{array}$ & technology & $\begin{array}{l}\text { total fixed } \\
\text { capital = } 1\end{array}$ & $\begin{array}{l}\text { High and medium-high companies' } \\
\text { share in total fixed capital of SEZ- } \\
\text { based companies in the county }\end{array}$ & $\begin{array}{l}\text { Authors' calculation based } \\
\text { on Ministry of Economy data }\end{array}$ \\
\hline $\begin{array}{l}\text { Employment } \\
\text { concentration }\end{array}$ & $\begin{array}{l}\text { gini_ } \\
\text { employment }\end{array}$ & $\%$ & $\begin{array}{l}\text { Gini index for concentration } \\
\text { of employment in SEZ-based } \\
\text { companies in the county }\end{array}$ & $\begin{array}{l}\text { Authors' calculation based } \\
\text { on Ministry of Economy data }\end{array}$ \\
\hline \multicolumn{5}{|c|}{ Fiscal variables } \\
\hline $\begin{array}{l}\text { Local government social } \\
\text { expenditures }\end{array}$ & gov_soc_exp & $\mathrm{mn}$ PLN & $\begin{array}{l}\text { The value of social transfers } \\
\text { of county and communities local } \\
\text { governments in the county }\end{array}$ & $\begin{array}{l}\text { Authors' calculation based } \\
\text { on Central Statistical Office } \\
\text { data }\end{array}$ \\
\hline $\begin{array}{l}\text { Local government } \\
\text { investment expenditures }\end{array}$ & $g o v \_i n v \_\exp$ & $\mathrm{mn}$ PLN & $\begin{array}{l}\text { The value of investment } \\
\text { expenditures of county and } \\
\text { communities local governments } \\
\text { in the county }\end{array}$ & $\begin{array}{l}\text { Authors' calculation based } \\
\text { on Central Statistical Office } \\
\text { data }\end{array}$ \\
\hline $\begin{array}{l}\text { Local government } \\
\text { revenues }\end{array}$ & gov_rev & $\mathrm{mn}$ PLN & $\begin{array}{l}\text { The value of county and } \\
\text { communities local governments } \\
\text { revenues in the county }\end{array}$ & $\begin{array}{l}\text { Authors' calculation based } \\
\text { on Central Statistical Office } \\
\text { data }\end{array}$ \\
\hline
\end{tabular}

Source: the authors 
Figure 1: Average annual investment growth in SEZ-based firms (top, thousand PLN) by county
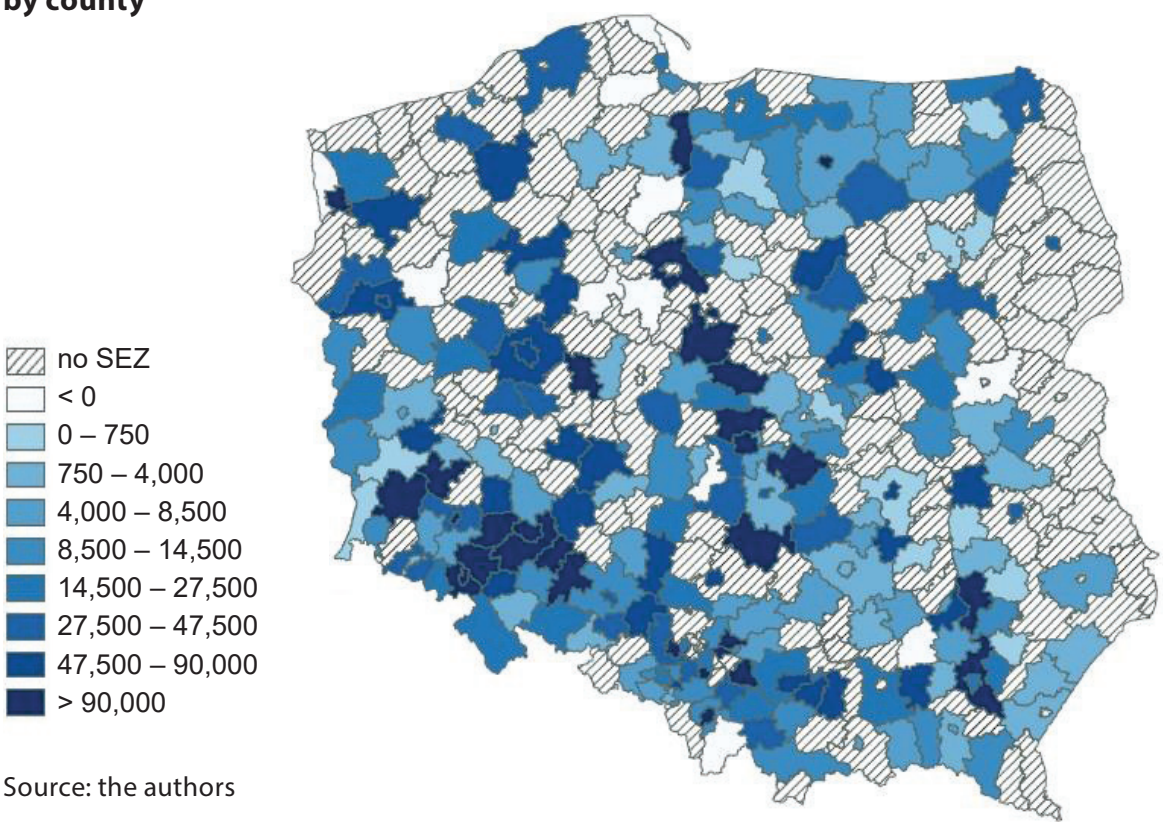

Source: the authors

Figure 2: Average annual employment growth (bottom, persons) by county

$\square$ no SEZ
$\square<0$
$\square$
$\square .0-8.0$
$\square .0-20.0$
$20.0-34.0$
$34.0-59.0$
$59.0-94.0$
$94.0-160.0$
$160.0-268.0$
$>268.0$

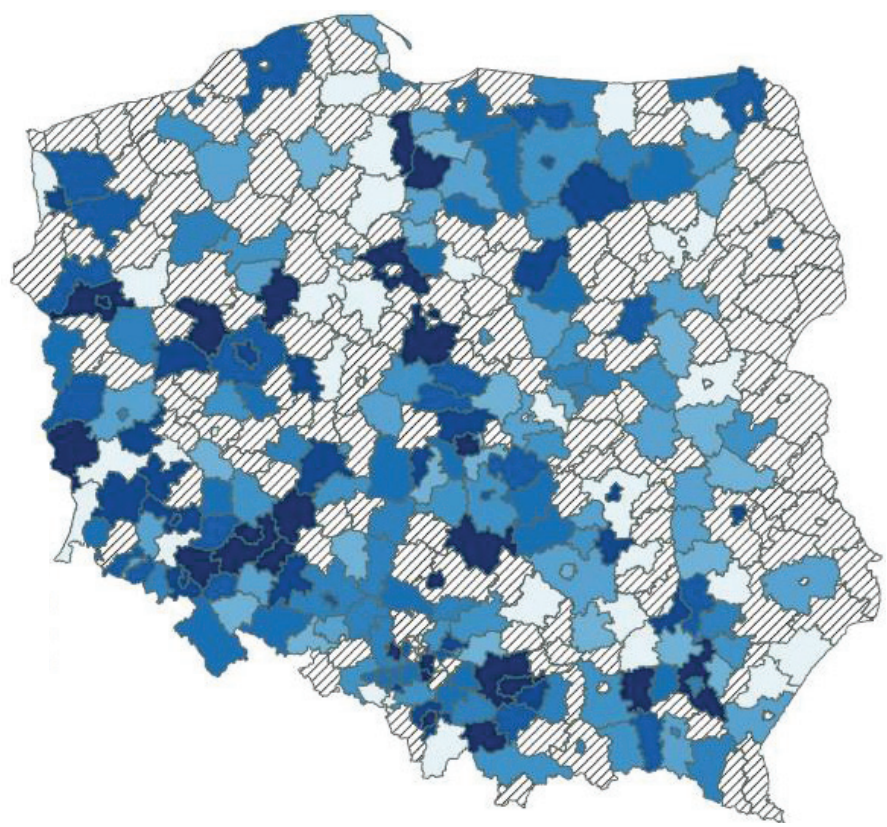

Source: the authors 
(iii) The SEZ-hosting counties differ in terms of their local market potential as well as their access to foreign markets. As indicated in Section 2, better access to markets and their higher potential are expected to boost SEZ performance. Local market size may be measured by the number of potential customers in respective SEZ-hosting counties (both final consumers and business clients) and their disposable income. Initial inspection of the data indicates that the better performing SEZ are located in counties with higher local market potential, i.e., significantly higher population density, larger number of firms and higher wage bill ${ }^{5}$. Surprisingly, the access to foreign markets did not enhance SEZ ability to attract investment: the SEZ based in the proximity of national borders underperformed in terms of investment growth. In contrast, employment growth in the SEZ located near German border was above average. The better performing SEZ are located in counties with significantly higher population density, larger number of firms and higher wage bill.

(iv) SEZ in each of the 14 groupings are governed by separate authorities and the quality of the governance might drive - to some extent - the performance of SEZ in each grouping. Although the performance of SEZ in each grouping may be influenced by a number of different factors (including local market potential; see above), it may also be, to some extent, driven by quality of the governance in individual zones. In this context, it is worth noting that there are striking differences in SEZ performance across the groupings. For example while there were no SEZ with above-average performance in the Slupsk and Suwalki groupings, $55 \%$ and $73 \%$ of the zones in the Legnica grouping and $50 \%$ and $46 \%$ in the Walbrzych grouping overperformed in terms of employment and investment growth, respectively.

(v) The investment and employment growth might also depend on the regional infrastructure quality. Indeed, taking the road density as a crude proxy for this factor, the data suggest that poor infrastructure quality hampered SEZ performance. For example, the poorly performing Slupsk and Suwalki groupings had the least developed road networks with densities well below the country average.

(vi) As could be expected, most of the SEZ benefited from relatively low wages and high availability of labour, including high-skilled employees, in counties of their operation. However, zones with above-average investment and employment growth were located in counties with slightly higher wages than in counties with the underperforming SEZ. This remains true also for wages in the year preceding the start of each zone's

5 It is worth noting that wage fund - apart from proxying local market potential - also mirrors local labour market conditions. From this viewpoint, wage fund constitutes a better proxy than employment level alone. For example, high employment could be perceived as an indicator of a receptive labour market and as such should be a positive signal for potential investors. However, if accompanied by high wages, it is rather a sign of hot local labour market and low availability of labour in this region. 
operations i.e., wages that the zone's initial investors took into consideration while deciding on location of their investments. In contrast, availability of labour, including highly educated employees, seems to be positively correlated with SEZ performance, especially in terms of employment growth.

(vii) One of the main tools to attract investment into the SEZ is income tax exemption. However, its scale seems not to drive the differences in SEZ performance. SEZ with above-average investment and employment growth offered slightly lower exemptions than those underperforming. Apparently the differences in tax exemptions granted were not big enough to compensate for variations in economic conditions in individual counties.

(viii) The changing time horizon by which firms could operate under preferential conditions in SEZ created uncertainty for potential investors and might influence their decisions to locate within zones. After a steady increase in 2003-2007, the average annual investment growth in 2008 and 2009 dropped significantly (Figure A4). One of the contributing factors - apart from the unfavourable global investment climate - may be heightened uncertainty related to planned changes in SEZ legal environment. Although investment growth remained relatively low in following years, it rebounded somewhat in 2014, i.e., after the second extension of the SEZ lifespan.

(ix) SEZ development was to a large extent driven by FDI inflow, with German, US and Dutch investors playing the biggest role. Considering that these countries - unlike Poland - are at the technological frontier, the differences in the share of foreign capital in SEZ may be behind the variations in SEZ performance. In fact, SEZ showing belowaverage investment and employment growth had a significantly lower share of foreign capital than the remaining zones (Table A5).

(x) Another factor that may influence SEZ performance has been the technological advancement of production processes. In Polish zones, manufacturing fixed assets were distributed roughly evenly between the firms of high- or medium-high technology and those of low- or medium-low technology. The high-tech firms were geographically strongly concentrated: 3 counties accounted for close to $60 \%$ of all the high-tech investments and 10 counties for almost $90 \%$ of them. Zones which hosted a relatively large share of highand medium-high technology manufacturing firms outperformed other zones in terms of both employment and investment growth (Table A5).

(xi) SEZ vary considerably in terms of concentration of firms. The average number of SEZ-based firms in counties with above-average SEZ investment and employment growth was over 3 times higher than in the underperforming ones. This may point to agglomeration effects.

(xii) These effects may also manifest themselves in strong concentration of both SEZ employment and investment. Distribution of investment of SEZ-based firms is strongly 
skewed, with very high fixed capital formation in firms at the top of the distribution. A similar conclusion holds for employment, as well as investment and employment aggregated at the county level (Table A6, Table A7).

\section{Conceptual Framework and Estimation Strategy}

The mechanism through which individual SEZ influence regional economic performance can be decomposed into four channels ${ }^{6}$ (see Figure A8):

A. First-round effects: the effects of SEZ incentives on companies' decisions to invest and create or retain employment in the SEZ-designated territory;

B. Induced effects: the effects induced by the functioning of SEZ-based companies in a (geographically or administratively) delimited region of the SEZ but outside the SEZ territory itself. These effects can be attributed to a number of economic processes that can have both a positive and a negative effect on the overall economic performance of the region. On the one hand, the induced effects can include the clustering of similar companies and vertical integration (backward and forward linkages). On the other hand, SEZ-based companies may crowd out existing firms or prevent the formation of new ones.

C. Spatially induced effects: externalities to neighbouring regions. These induced effects might, in principle, take the same forms as the induced effects within the region of SEZ designation but materialize outside that region. Examples include hiring employees from outside the hosting region.

D. Reverse inductions: the economic performance of regions neighbouring the SEZ can be altered by the economic zone designation; thus, some induced effects (again positive and negative) from neighbouring regions to the SEZ region might occur.

The vast majority of the literature examines the joint effect of channels A and B using dummy variables indicating zone existence in a particular region and period. The variable is incorporated into a (cross-sectional or panel data) standard model of regional employment or investment. The estimates capture the change in employment and investment in the SEZ-hosting county, i.e., the sum of changes created directly by firms attracted to SEZ (channel A) and spillovers from their operation to firms based in the SEZ-hosting county, but outside the SEZ itself (channel B). These estimates are interpreted as the average effect of a SEZ on the economic outcomes of the hosting region. The main problem caused by such an approach is lack of causality: it assumes that the establishment

6 The described analytical framework is based on Cizkowicz et al. (2016) and enhanced to include factors relevant to first-round effects of SEZ functioning. 
of the zone itself influences the economic performance of the region. In reality, however, this influence is exerted by the companies that are located in the zone; in particular, lack of companies means that there is not even a potential impact. In Cizkowicz et al. (2016), we analysed the impact of SEZ given the development of economic activity in a SEZ territory (channels B, C and D). In this study, on the other hand, we focus solely on firstround effects (channel A), namely the impact of particular SEZ characteristics (e.g., level of tax exemption, number of companies, share of foreign capital, etc.) and SEZ-hosting region characteristics (e.g., labour force availability and skills, average wages, region's economic specialization) on economic activity within the zone territory. The stylized facts presented in Section 4 do indeed point to large differences in SEZ employment and investment growth across counties. To analyse the determinants of these differences, we use a set of panel data models covering all the 235 counties which hosted SEZ throughout the period 2003-2015. We measure SEZ development by the net number of jobs created by firms operating in the SEZ $i$ in the year $t$ (d_emp $i t$; Model 1) and the net fixed capital formation of these firms ( $d_{-}$cap ${ }_{i t}$; Model 2):

$$
d_{-} e m p_{i t}=\alpha_{0}^{e m p}+\boldsymbol{X}_{i(t-1)} \boldsymbol{\beta}^{e m p}+\boldsymbol{Z}_{i(t-1)} \gamma^{e m p}+\varepsilon_{i t}
$$

and

$$
d_{-} c a p_{i t}=\alpha_{0}^{c a p}+\boldsymbol{X}_{i(t-1)} \boldsymbol{\beta}^{c a p}+\boldsymbol{Z}_{i(t-1)} \gamma^{c a p}+\varepsilon_{i t}
$$

Such an approach allows a direct estimation of the impact of particular groups of determinants on the development of economic activity within a zone, which is not possible in an approach based on the use of binary variables identifying the location of zones.

We divided the determinants of SEZ development into two groups (a detailed description of the variables is presented in Table A5). The first group, included in the vector $\boldsymbol{X}_{i(t-1)}$, consists of variables representing structural characteristics of the local economy which may drive firms' decisions to locate in a particular county:

(i) relative costs of labour measured as the average wage in the county $i$ in the year $t$ expressed in percentage of average wage in Poland in the year $t\left(w a g e \_a v_{\mathrm{it}}\right)$;

(ii) wage bill (wage fund $d_{i t}$, which is the product of average wage in the county $i$ in the year $t$ and average employment;

(iii) size of local labour market measured by the number of persons active on the labour market $\left(\right.$ active $\left._{i t}\right)$ and the availability of labour force expressed as the number of persons registered as unemployed ( unemployed $_{i t}$ );

(iv) quality of untapped labour force approximated by the share of persons with primary education in the number of registered unemployed (unemployed_low $w_{i t}$ ) and the number of tertiary education graduates per 10 thousand inhabitants ( graduates $_{i t}$ ); 
(v) quality of the county's infrastructure measured by road density per square $\mathrm{km}$ $\left(\right.$ road_density $\left.{ }_{i t}\right)$;

(vi) the county's economic specialization profile approximated by the value of industrial production per 10 thousand inhabitants (industrial_prod ${ }_{i}$ );

(vii) location near national border represented by a dummy variable (border) taking the value of 1 if the county $i$ shares a border with a foreign country and 0 otherwise.

The second group of variables - included in the vector $\boldsymbol{Z}_{i(t-1)}-$ describes SEZ characteristics:

(i) planned lifetime of SEZ's scheme known in the year $t$ (remaining years);

(ii) maximum SEZ tax exemption for the county $i$ in the year $t$ (max_exmpt $t_{i t}$ );

(iii) agglomeration economies/diseconomies defined as positive/negative effects experienced by firms when locating near each other; we use the number of firms located in the $i$-th SEZ in the year $t\left(n_{-} S E Z_{-}\right.$firms $\left.{ }_{i t}\right)$ and their concentration measured by the Gini indices for employment and investment (gini_employment ${ }_{i t}$; gini_investment ${ }_{i t}{ }^{7}$ );

(iv) ownership structure of existing firms measured by the share of fixed capital in SEZ-based firms owned by foreign investors in total fixed capital in SEZ-based firms in the county $\left(\right.$ share_foreign $_{i t}{ }^{8}$ ) and technological intensity of firms expressed as high and medium-high tech firms' share in total fixed capital of SEZ-based firms in the county (technolog $y_{i t}{ }^{9}$ ).

One-year lags of all the variables, except the dummy border, are included in the models, which ensures that only the analysed factors may exert an impact on the dependent variables and not vice versa.

We estimate the models starting with pooled estimator (OLS), which ignores the possible individual effects - unobservable characteristics of particular counties that affect the dependent variable. A functional form assuming the absence of individual effects has been chosen on purpose. A major part of the variables used in Models 1 and 2 describes differences in structural characteristics of counties or SEZ located in the counties and

7 The Gini index for employment and investment in a given SEZ was calculated based on the firmlevel dataset provided by the Ministry of the Economy, including information on employment and total investment of individual firms operating in SEZ.

8 The variable share foreign ${ }_{i t}$ was calculated based on the firm-level dataset provided by the Ministry of the Economy that included, inter alia, data on capital formation of SEZ-based companies and information whether the firm was foreign-owned or not. share foreig $n_{i t}$ equals the share of fixed capital of firms with foreign capital in total fixed capital in SEZ-based firms in a given SEZ.

9 The variable technolog $y_{i t}$ was calculated based on the firm-level dataset provided by the Ministry of the Economy as a share of fixed capital of firms operating in high and medium-high industries (according to classification used by Eurostat) in total fixed capital of companies based in a given SEZ. 
would, therefore, be correlated with individual effects ${ }^{10}$. In practice, this would mean that a major part of the differences in the level of dependent variables in the cross-sectional dimension could not be assigned to the explanatory variables but instead would be assigned to the individual effects, which are not directly interpreted. It should be stressed that the choice is supported by the characteristics of the data, as the Wald and Breusch-Pagan tests indicate that in the case of both models, $\mathrm{H} 0$ of lack of statistically significant individual effects, fixed or random respectively, cannot be rejected at the $5 \%$ significance level.

The results based on the OLS estimator may be biased due to several methodological and specification-related problems. The first one is the possible cross-sectional dependence (or spatial correlation) of error terms. In the analysed model, it is equivalent to the assumption that there are unobserved time-varying omitted variables common for all the counties which impact each county in a different way. Indeed, the results of the Pesaran test (2004) for cross-sectional dependence indicate that this is a characteristic of the data set used. If these unobservable common factors are uncorrelated with the independent variables, the coefficient estimates based on the OLS regressions are consistent, but the standard errors estimates are biased. Therefore, we use the Driscoll and Kraay (1998) nonparametric covariance matrix estimator (DK; Models 5 and 6), which corrects for the error structure spatial dependence. The estimator also addresses the second problem, which is the standard errors bias due to potential heteroscedasticity and autocorrelation of the error terms. We are aware of the weaknesses of this estimator when the number of cross-sectional units is much larger than the number of time periods as in our panel. However, we take into account evidence provided by Monte Carlo simulations, according to which, even for panels with a very short time dimension, in the case of cross sectional dependence it is more robust than standard estimators (Hoechle, 2006).

The third problem is endogeneity due to the potential correlation of the regressors with the error term. This concern is alleviated to some extent by using the first lag of explanatory variables. One of the possible solutions is to use an instrumental variable estimator. Such an estimator is asymptotically consistent, but it may be biased when applied to samples as small as ours. We assess the severity of the endogeneity problem through robustness analysis, enhancing the set of control variables with:

(i) dummies for time-fixed effects, which account for time-specific factors, e.g., limits on SEZ area, influencing both control and dependent variables;

10 The estimator applied in the case of correlation between explanatory variables and the individual effects is the estimator proposed by Hausman and Taylor (1981). The condition for applying the estimator based on the instrumental variables method is, however, the determination of the adequate set of instrumental variables that are not correlated with the individual effects. 
(ii) variables measuring local governments' revenues and social and investment expenditures ( $g o v_{-} r e v_{i t}$ gov_soc_exp $p_{i t} g o v_{-} i n v_{-} \exp _{i t}{ }^{11}$ ) in order to check whether the results are driven by local fiscal policies;

(iii) dummies for each of the 14 SEZ groupings used to capture possible impacts of governance quality on SEZ development.

We estimate the two basic models in 5 versions using different sets of control variables and two estimators: pooled (OLS), and Driscoll-Kraay (DK). We are aware that the obtained results may still be affected by some of the aforementioned problems, and that conclusions drawn on their basis should be treated with caution. The estimation is based on the entire sample and it is implicitly assumed that the structural parameters of the models are stable and independent of the characteristics of individual SEZ.

It is important to validate this assumption, since the initial inspection of data suggests that the strength of individual factors that attract investors may differ significantly across SEZ. We verify this assumption by dividing the sample by quartiles of 3 independent variables describing SEZ characteristics, which - as indicated in Section 4 - varied significantly across SEZ located in individual counties, and estimating the model parameters separately in such subsamples. ${ }^{12}$ The variables used for subsample separation are: (i) the size of the SEZ measured respectively by employment and capital outlays; (ii) the share of foreign capital; (iii) the share of high and medium-high tech firms in employment and capital outlays respectively. As a consequence, each of two basic models is estimated in 12 forms.

\section{Estimation Results}

The analysis of results starts with the outcomes for the whole sample presented in Table 3 and Table A9. They are based on basic OLS and $\mathrm{DK}^{13}$ estimation of employment and capital growth equations (Models 1-2 and 5-6, respectively), followed by estimations of enhanced specification with time-fixed effects (Models 3 and 4), variables measuring local governments' revenues and expenditures (Models 7 and 8) and dummies for SEZ groupings (Models 9 and 10).

11 The variables have been calculated in the following way: gov_rev-sum of revenues of a given county and the constituent communities, gov_soc_exp - sum of expenditures of the given county and the constituent communities in the section 'social security' of the budget, gov_inv_exp - sum of fixed capital investment expenditures of the given county and the constituent communities.

12 Alternative approaches may rely on the Mean-Group estimator (Pesaran and Smith, 1995) and quantile regression, both of which are not applicable in our case due to data scarcity in the panel structure of our data set.

13 As the Pesaran test indicates presence of cross-section dependence in both employment and investment models, we treat the results based on the DK estimator as more reliable compared to the OLS estimates. 
Table 3: Estimation results

\begin{tabular}{|c|c|c|c|c|c|c|c|c|c|}
\hline & \multicolumn{9}{|c|}{ Dependent variable: } \\
\hline & \multicolumn{4}{|c|}{ d_employment } & & \multicolumn{4}{|c|}{ d_investment } \\
\hline & Model 1 & Model 3 & Model 5 & Model 7 & & Model 2 & Model 4 & Model 6 & Model 8 \\
\hline \multirow[t]{2}{*}{$\begin{array}{l}\text { Specifica- } \\
\text { tion }\end{array}$} & OLS & $\begin{array}{c}\text { OLS, } \\
\text { time-fixed } \\
\text { effects }\end{array}$ & $\begin{array}{c}\text { Driscoll- } \\
\text { Kraay }\end{array}$ & $\begin{array}{c}\text { Driscoll- } \\
\text { Kraay, fis- } \\
\text { cal control } \\
\text { variables }\end{array}$ & $\begin{array}{l}\text { Specifica- } \\
\text { tion }\end{array}$ & OLS & $\begin{array}{l}\text { OLS time- } \\
\text { fixed } \\
\text { effects }\end{array}$ & $\begin{array}{c}\text { Driscoll- } \\
\text { Kraay }\end{array}$ & $\begin{array}{c}\text { Driscoll- } \\
\text { Kraay, fis- } \\
\text { cal control } \\
\text { variables }\end{array}$ \\
\hline & (1) & (3) & (2) & (4) & & (5) & (7) & (6) & (8) \\
\hline wage_av & $\begin{array}{l}37.9572 \\
(0.2193)\end{array}$ & $\begin{array}{l}12.5494 \\
(0.0725)\end{array}$ & $\begin{array}{l}37.9572 \\
(0.3126)\end{array}$ & $\begin{array}{l}56.3501 \\
(0.4785)\end{array}$ & wage_av & $\begin{array}{l}4.1 e+07 \\
(0.7750)\end{array}$ & $\begin{array}{l}3.2 e+07 \\
(0.5952)\end{array}$ & $\begin{array}{l}4.1 e+07 \\
(1.2323)\end{array}$ & $\begin{array}{l}3.1 e+07 \\
(0.8990)\end{array}$ \\
\hline wage_fund & $\begin{array}{c}-0.8882^{* * *} \\
(-3.8334)\end{array}$ & $\begin{array}{c}-0.8165 * * * \\
(-3.4459) \\
\end{array}$ & $\begin{array}{c}-0.8882^{* * *} \\
(-4.3299)\end{array}$ & $\begin{array}{c}-0.8682 * * * \\
(-4.0968)\end{array}$ & wage_fund & $\begin{array}{c}-1.9 \mathrm{e}+05^{* * *} \\
(-2.6932)\end{array}$ & \begin{tabular}{|c|}
$-1.7 \mathrm{e}+05^{* *}$ \\
$(-2.2715)$
\end{tabular} & $\begin{array}{c}-1.9 e+05^{* * *} \\
(-7.5563) \\
\end{array}$ & $\begin{array}{c}-1.9 \mathrm{e}+05^{* * * *} \\
(-5.7013)\end{array}$ \\
\hline active & $\begin{array}{c}0.0040^{* * *} \\
(3.3564)\end{array}$ & $\begin{array}{c}0.0036^{* * *} \\
(2.9142)\end{array}$ & $\begin{array}{c}0.0040^{* * *} \\
(4.7745)\end{array}$ & $\begin{array}{c}0.0039^{* * *} \\
(4.4011)\end{array}$ & active & $\begin{array}{c}929.0870^{* *} \\
(2.5378)\end{array}$ & $\begin{array}{c}776.2571^{* * *} \\
(2.0491)\end{array}$ & \begin{tabular}{|c|}
$929.0870^{* * * *}$ \\
$(7.2375)$
\end{tabular} & $\begin{array}{c}893.4884^{* * * *} \\
(5.0358)\end{array}$ \\
\hline unemployed & $\begin{array}{c}0.0031 \\
(0.6106) \\
\end{array}$ & $\begin{array}{c}0.0039 \\
(0.7341)\end{array}$ & $\begin{array}{c}0.0031 \\
(1.0387)\end{array}$ & $\begin{array}{c}0.0031 \\
(1.1250)\end{array}$ & uneployed & $\begin{array}{c}679.8224 \\
(0.4312) \\
\end{array}$ & $\begin{array}{r}955.6011 \\
(0.5748) \\
\end{array}$ & $\begin{array}{c}679.8224 \\
(0.7100) \\
\end{array}$ & $\begin{array}{c}775.8046 \\
(0.7487)\end{array}$ \\
\hline $\begin{array}{l}\text { unem- } \\
\text { ployed_low }\end{array}$ & $\begin{array}{c}691.0645^{* * *} \\
(2.6484)\end{array}$ & $\begin{array}{c}527.7310^{*} \\
(1.8998)\end{array}$ & $\begin{array}{c}691.0645^{* *} \\
(2.7414)\end{array}$ & $\begin{array}{c}666.7324^{* *} \\
(2.8082)\end{array}$ & $\begin{array}{l}\text { unem- } \\
\text { ployed_low }\end{array}$ & $\begin{array}{c}2.2 \mathrm{e}+08^{* * *} \\
(2.7273)\end{array}$ & $\begin{array}{c}1.6 \mathrm{e}+08^{*} \\
(1.8587)\end{array}$ & $\begin{array}{c}2.2 \mathrm{e}+08^{* * *} \\
(5.1935)\end{array}$ & $\begin{array}{c}2.3 \mathrm{e}+08^{* * * *} \\
(4.2024)\end{array}$ \\
\hline graduates & $\begin{array}{l}-0.0042 \\
(-0.6231) \\
\end{array}$ & $\begin{array}{c}-0.0022 \\
(-0.3289) \\
\end{array}$ & $\begin{array}{l}-0.0042 \\
(-1.1894) \\
\end{array}$ & $\begin{array}{l}-0.0041 \\
(-1.3152) \\
\end{array}$ & graduates & $\begin{array}{c}-3.4 \mathrm{e}+03^{*} \\
(-1.6543)\end{array}$ & $\begin{array}{l}-2.7 \mathrm{e}+03 \\
(-1.2878) \\
\end{array}$ & \begin{tabular}{|c|}
$-3.4 \mathrm{e}+03^{* *}$ \\
$(-2.3076)$
\end{tabular} & $\begin{array}{c}-3.3 e+03^{* *} \\
(-2.2421)\end{array}$ \\
\hline $\begin{array}{l}\text { ind } \\
\text { production }\end{array}$ & $\begin{array}{c}0.0017^{* *} \\
(1.9705)\end{array}$ & $\begin{array}{c}0.0019^{* *} \\
(2.1550)\end{array}$ & $\begin{array}{c}0.0017 \\
(1.1003)\end{array}$ & $\begin{array}{c}0.0017 \\
(1.1125)\end{array}$ & $\begin{array}{l}\text { ind } \\
\text { production }\end{array}$ & $\begin{array}{c}459.8013^{*} \\
(1.7302)\end{array}$ & $\begin{array}{c}502.2992^{*} \\
(1.8761)\end{array}$ & $\begin{array}{c}459.8013^{*} \\
(1.9458)\end{array}$ & $\begin{array}{c}459.8266 \\
(1.6617)\end{array}$ \\
\hline $\begin{array}{l}\text { roads } \\
\text { density }\end{array}$ & $\begin{array}{c}0.2012 \\
(0.8869)\end{array}$ & $\begin{array}{c}0.1625 \\
(0.7199)\end{array}$ & $\begin{array}{c}0.2012 \\
(0.9694)\end{array}$ & $\begin{array}{c}0.2303 \\
(0.9985)\end{array}$ & $\begin{array}{l}\text { roads } \\
\text { density }\end{array}$ & $\begin{array}{l}1.9 e+04 \\
(0.2710)\end{array}$ & $\begin{array}{l}5.1 e+03 \\
(0.0737)\end{array}$ & $\begin{array}{l}1.9 e+04 \\
(0.4033)\end{array}$ & $\begin{array}{l}7.8 \mathrm{e}+03 \\
(0.1441)\end{array}$ \\
\hline border & $\begin{array}{l}-22.0415 \\
(-0.4802)\end{array}$ & $\begin{array}{l}-19.3378 \\
(-0.4238)\end{array}$ & $\begin{array}{l}-22.0415 \\
(-0.9992)\end{array}$ & $\begin{array}{l}-21.4994 \\
(-1.0924)\end{array}$ & border & $\begin{array}{l}-1.2 \mathrm{e}+07 \\
(-0.8676)\end{array}$ & $\begin{array}{l}-1.1 e+07 \\
(-0.7938)\end{array}$ & $\begin{array}{c}-1.2 \mathrm{e}+07^{*} \\
(-2.0017)\end{array}$ & $\begin{array}{l}-1.2 \mathrm{e}+07 \\
(-1.6194)\end{array}$ \\
\hline $\begin{array}{l}\text { remaining } \\
\text { years }\end{array}$ & $\begin{array}{c}23.8450^{* * *} \\
(2.6916)\end{array}$ & $\begin{array}{c}142.2880^{* *} \\
(2.0099)\end{array}$ & $\begin{array}{c}23.8450 * * \\
(2.7405)\end{array}$ & $\begin{array}{c}24.8535^{* *} \\
(2.8919)\end{array}$ & $\begin{array}{l}\text { remaining } \\
\text { years }\end{array}$ & $\begin{array}{l}2.7 e+06 \\
(1.0071)\end{array}$ & $\begin{array}{c}5.7 \mathrm{e}+07^{* * *} \\
(2.5976)\end{array}$ & $\begin{array}{l}2.7 e+06 \\
(1.2608)\end{array}$ & $\begin{array}{c}2.6 e+06 \\
(1.1188)\end{array}$ \\
\hline max_exmpt & $\begin{array}{c}361.3305 \\
(1.4623)\end{array}$ & $\begin{array}{l}49.3419 \\
(0.1668)\end{array}$ & $\begin{array}{c}361.3305^{* *} \\
(2.3392)\end{array}$ & $\begin{array}{c}310.9967^{* *} \\
(2.3809)\end{array}$ & max_exmpt & $\begin{array}{l}3.7 e+07 \\
(0.4904)\end{array}$ & $\begin{array}{l}-8.5 e+07 \\
(-0.9350)\end{array}$ & $\begin{array}{l}3.7 e+07 \\
(0.8483)\end{array}$ & $\begin{array}{l}3.9 e+07 \\
(0.7842)\end{array}$ \\
\hline n_SEZ_firms & $\begin{array}{c}1.4879 \\
(0.6803)\end{array}$ & $\begin{array}{c}1.4738 \\
(0.6781)\end{array}$ & $\begin{array}{c}1.4879 \\
(0.3490)\end{array}$ & $\begin{array}{c}1.4682 \\
(0.3448)\end{array}$ & $\begin{array}{l}\text { n_SEZ } \\
\text { firms }\end{array}$ & $\begin{array}{c}1.9 \mathrm{e}+06^{* * *} \\
(2.7270)\end{array}$ & $\begin{array}{c}1.9 \mathrm{e}+06^{* * *} \\
(2.7650)\end{array}$ & $\begin{array}{l}1.9 e+06 \\
(1.3576)\end{array}$ & $\begin{array}{l}1.9 \mathrm{e}+06 \\
(1.3277)\end{array}$ \\
\hline $\begin{array}{l}\text { share } \\
\text { foreign }\end{array}$ & $\begin{array}{l}60.6065 \\
(1.5039)\end{array}$ & $\begin{array}{l}56.5120 \\
(1.4043)\end{array}$ & $\begin{array}{c}60.6065^{* *} \\
(2.3556)\end{array}$ & $\begin{array}{c}62.2311^{* * *} \\
(2.3334)\end{array}$ & $\begin{array}{l}\text { share } \\
\text { foreign }\end{array}$ & $\begin{array}{c}2.5 \mathrm{e}+07^{* *} \\
(1.9882)\end{array}$ & $\begin{array}{c}2.2 \mathrm{e}+07^{*} \\
(1.7624)\end{array}$ & $\begin{array}{c}2.5 \mathrm{e}+07^{* * *} \\
(3.2312)\end{array}$ & $\begin{array}{c}2.4 \mathrm{e}+07^{* *} \\
(2.5735)\end{array}$ \\
\hline technology & $\begin{array}{l}18.0905 \\
(0.4046)\end{array}$ & $\begin{array}{l}19.1471 \\
(0.4304)\end{array}$ & $\begin{array}{l}18.0905 \\
(0.9247)\end{array}$ & $\begin{array}{l}19.4052 \\
(1.0850)\end{array}$ & technology & $\begin{array}{c}3.0 \mathrm{e}+07^{* *} \\
(2.1830)\end{array}$ & $\begin{array}{c}2.9 \mathrm{e}+07^{* *} \\
(2.1259)\end{array}$ & $\begin{array}{c}3.0 \mathrm{e}+07^{* *} \\
(2.9001)\end{array}$ & $\begin{array}{c}2.9 \mathrm{e}+07^{* *} \\
(2.5311)\end{array}$ \\
\hline $\begin{array}{l}\text { gini } \\
\text { employment }\end{array}$ & $\begin{array}{l}89.7748 \\
(1.3797)\end{array}$ & $\begin{array}{l}95.5561 \\
(1.4748)\end{array}$ & $\begin{array}{l}89.7748 \\
(1.1037)\end{array}$ & $\begin{array}{l}88.3840 \\
(1.0703)\end{array}$ & - & - & - & - & - \\
\hline - & - & - & - & - & $\begin{array}{l}\text { gini } \\
\text { investment }\end{array}$ & $\begin{array}{c}3.7 \mathrm{e}+07^{*} \\
(1.7493)\end{array}$ & $\begin{array}{c}3.9 \mathrm{e}+07^{*} \\
(1.8484)\end{array}$ & $\begin{array}{l}3.7 e+07 \\
(1.2207)\end{array}$ & $\begin{array}{l}3.7 e+07 \\
(1.2703)\end{array}$ \\
\hline gov_soc_exp & - & - & - & $\begin{array}{l}6.5 e+04 \\
(0.6013)\end{array}$ & soc_pop & - & - & - & $\begin{array}{l}-2.9 e+10 \\
(-1.3273)\end{array}$ \\
\hline gov_inv_exp & - & - & - & $\begin{array}{l}3.8 e+04 \\
(0.8817)\end{array}$ & $i n v \_p o p$ & - & - & - & $\begin{array}{l}1.8 e+09 \\
(0.1384)\end{array}$ \\
\hline gov_rev & - & - & - & $\begin{array}{l}-2.1 e+04 \\
(-1.0875)\end{array}$ & rev_pop & - & - & - & $\begin{array}{l}1.7 e+09 \\
(0.2457)\end{array}$ \\
\hline $\begin{array}{l}\text { year } \\
\text { dummies }\end{array}$ & NO & YES & NO & NO & $\begin{array}{l}\text { year } \\
\text { dummies }\end{array}$ & NO & YES & NO & NO \\
\hline constant & $\begin{array}{c}-7.4 \mathrm{e}+02^{* * *} \\
(-3.2810)\end{array}$ & $\begin{array}{c}-2.0 \mathrm{e}+03^{* *} \\
(-2.3744)\end{array}$ & $\begin{array}{c}-7.4 \mathrm{e}+02^{* *} \\
(-3.0922)\end{array}$ & $\begin{array}{c}-7.2 \mathrm{e}+02^{* * *} \\
(-3.1707)\end{array}$ & constant & $\begin{array}{c}-1.7 \mathrm{e}+08^{* *} \\
(-2.4741)\end{array}$ & $\begin{array}{c}-7.7 \mathrm{e}+08^{* * *} \\
(-2.9452)\end{array}$ & $\mid \begin{array}{c}-1.7 \mathrm{e}+08^{* * * *} \\
(-3.5679)\end{array}$ & $\begin{array}{c}-1.6 \mathrm{e}+08^{* *} \\
(-2.3094)\end{array}$ \\
\hline $\mathbf{N}$ & 1,826 & 1,826 & 1,826 & 1,826 & $\mathbf{N}$ & 1,826 & 1,826 & 1,826 & 1,826 \\
\hline $\mathbf{N} \mathbf{g}$ & 235 & 235 & 235 & 235 & N_g & 235 & 235 & 235 & 235 \\
\hline$R^{2}$ & 0.043 & 0.0615 & 0.043 & 0.0440 & $R^{2}$ & 0.056 & 0.0619 & 0.056 & 0.0560 \\
\hline
\end{tabular}

Notes: Table 3 presents Models 1-8 estimation results on the full sample of SEZ-hosting counties. Dependent variables are the net number of jobs created by firms operating in SEZ $i$ in the year $t(d$ employment, Models $1,3,5,7)$ and net fixed capital formation of these firms (d investment, models $2,4,6,8$ ). Detailed specifications of Models 1-8 are discussed in Section 5. Variables definitions are reported in Table 4. $t$-statistics for coefficient estimates are given in parentheses. Stars denote estimates significance at $1 \%\left({ }^{* * *}\right), 5 \%\left(^{* *}\right)$ and $10 \%\left({ }^{*}\right)$ levels.

Source: the authors 
Labour costs $\left(\right.$ wage_av $\left.v_{\mathrm{it}}\right)$ have no significant ${ }^{14}$ impact on employment or investment growth in SEZ. This result seems counterintuitive, as one could expect that investors prefer locations with low labour costs. However, combining this result with the significant negative impact of wage bill (wage fund fit $_{\text {) }}$ and the positive impact of the number of persons active on the labour market (active $e_{i t}$ ) yields a more coherent interpretation. Note that wage fund $_{i t}$ is the product of average wage level and number of persons employed while active $_{i t}$ is the sum of number of persons employed and unemployed. As a consequence, wage fund $_{i t}$ represents a quasi-interaction term between active ${ }_{i t}$ and wage_av ${ }_{i t}$. The positive, statistically significant parameter estimate for active $_{i t}$ suggests that firms prefer counties with deeper labour markets. However, this effect is moderated by the level of average wages - as evidenced by the statistically significant negative parameter for wage fund ${ }_{i t}$ In other words, firms choosing a SEZ location seek counties with the largest labour pool and, among them, pick those with the lowest average wages.

The number of unemployed and the number of tertiary education graduates have no significant impact on employment or investment growth of SEZ firms. In contrast, the number of unemployed with primary education has a positive impact on both dependent variables. These results indicate that SEZ development is driven by access to low-skilled labour. This points to the fulfilment of one of the main objectives of SEZ, namely to increase labour demand in underdeveloped regions (also in terms of human capital underdevelopment).

The positive and significant impact of industrial production per capita on both independent variables may indicate that firms prefer SEZ located in counties which provide an opportunity to agglomerate with other industrial firms. However, this result may be driven by some specific features of more industry-oriented counties (e.g., favourable location), which create important advantages for industrial firms. However, the impact of industrial production is not very robust to changes in model specifications.

The length of roads per $\mathrm{km}^{2}$ has no significant impact on either of the dependent variables. This may indicate that SEZ investors might be more interested in the quality than the density of transportation networks, as the former is the key determinant of transportation costs and time. Moreover, for firms operating outside local markets,

14 All the estimated models are characterized by a relatively low level of R-squared. There are two complementary explanations for this state. Firstly, in panels where the cross-sectional dimension is significantly larger than the time dimension (as in our case: $\mathrm{T}=12, \mathrm{~N}=235$ ), the low level of R-squared is rather normal. Secondly, model specification are based on first differences, not levels, of employment and investment of SEZ-located companies, which further reduces the expected R-squared ratio. It is worth noting that estimates based on employment and investment levels (not presented in the study) were characterised by a much higher R-squared ratio (between 0.58 and 0.67 ); however, it was due to spurious regression rather than good model-data fit. 
access to interregional transportation might be of more importance than density of local roads. Similarly, somewhat counterintuitively, location of a SEZ-hosting county near a national border is not an important factor of SEZ development.

The positive and statistically significant impact of the planned lifetime of a SEZ known in the year $t$ indicates that uncertainty in this respect hinders SEZ development in terms of employment and - for some specifications - investment.

The maximum tax exemption seems not to affect the rate of employment and investment growth of SEZ (its impact is not robust to changes in specifications).

The results obtained for the planned lifetime and the maximum tax exemption might also be interpreted from another perspective: a firm making large investments but operating at low margins and, consequently, paying low corporate income tax might never be able to take full advantage of the tax allowance. The overall tax benefit derived by that kind of firm depends entirely on the time horizon in which the tax allowance will remain in place and not on the level of the tax allowance itself.

A higher number of firms located in a particular SEZ and their concentration does not translate into faster growth of investment and employment ${ }^{15}$. This may indicate that positive effects of agglomeration do not outweigh negative effects of competition for labour force. In contrast, the results indicate that clustering among SEZ firms in terms of FDI strengthens employment and investment growth in SEZ. The same holds for the impact of technological advancement on investment growth.

In the next step, the basic specification of Equations (1) and (2) is estimated on subsamples delimited by the quartiles of distribution of the three variables indicated in Section 5. The estimation results are divided according to the distribution of those independent variables and are presented in Tables 4, 5 and 6.

\section{(i) SEZ size}

- Table 4 shows the estimation results on the subsamples selected according to employment and fixed capital formation quartiles. The results indicate that firms' preference for locations with deepest local labour markets and - among them - with the lowest wages is statistically significant only for large and very large SEZ (with abovemedian employment or capital outlays). Furthermore, the larger the SEZ, the stronger the impact of these factors. This result is consistent with economic intuition: the larger the SEZ, the stronger the competition for employees and the more important the labour availability for the location decision.

\footnotetext{
15 The opposite holds only for the investment equation estimated using OLS.
} 
- The availability of low-skilled employees is most important for the development of very large SEZ (above the $75^{\text {th }}$ percentile). This may relate to the fact that in large, capital-intensive firms (e.g., in selected manufacturing industries) profitability is driven by economies of scale, while labour skills are not of primary importance.

- Firms in SEZ with higher per capita value of industrial production develop faster only in the case of middle-sized SEZ $\left(25^{\text {th }}-75^{\text {th }}\right.$ percentile of employment and capital outlays). This result indicates that in small SEZ the incentive for investors to locate close to existing industrial firms is too weak to create agglomeration effects, possibly due to low likelihood of finding suppliers and purchasers among existing local firms. In turn, in the case of large SEZ, agglomeration of industrial firms may be limited due to higher specialisation and clustering of firms within the zone.

- The planned lifetime of a SEZ scheme in a given year gains in importance for SEZ employment growth with increasing SEZ size.

- The maximum tax exemption exerts some positive impact only on SEZ development in the largest SEZ.

- The effect of clustering with respect to foreign capital share and technological advancement on SEZ development was not confirmed by the subsample estimation results.

(ii) Share of foreign capital

- The labour market size has a statistically significant impact on employment growth, irrespective of foreign capital share in a given SEZ. However, this impact is the strongest for SEZ with highest foreign capital involvement (above the $75^{\text {th }}$ percentile). In turn, as far as investment growth is concerned, labour market size proved to be an important factor only for SEZ with above-median foreign capital shares. These results indicate that labour market size is a more important factor in location of FDIs than domestic investment.

- Similarly, although the number of unemployed persons has no impact on the growth of capital outlays in the whole sample of firms, it increases the investment growth in zones with above-median foreign capital shares.

- The effect of the planned lifetime of SEZ on employment growth increases with rising share of foreign capital, which may indicate that foreign-owned firms are more aware of the consequences of SEZ tax exemption models than domestic firms.

(iii) Technological advancement

- Labour market size and average wages have a significant impact on employment and investment growth of both low- and high-tech firms. The strength of this impact does not depend on SEZ technological advancement. 
Table 4: Estimation results: model estimated on whole sample and subsamples delimited by quartiles of distribution of employment (left panel) and investment (right panel)

\begin{tabular}{|c|c|c|c|c|c|c|c|c|c|c|}
\hline \multirow{4}{*}{ Specification } & \multicolumn{10}{|c|}{ Dependent variable: } \\
\hline & \multicolumn{5}{|c|}{ d_employment } & \multicolumn{5}{|c|}{$d_{-}$investment } \\
\hline & Total & $\begin{array}{c}\text { I } \\
\text { quartile }\end{array}$ & $\begin{array}{c}\text { II } \\
\text { quartile }\end{array}$ & $\begin{array}{c}\text { III } \\
\text { quartile }\end{array}$ & $\begin{array}{c}\text { IV } \\
\text { quartile }\end{array}$ & Total & $\begin{array}{c}\text { I } \\
\text { quartile }\end{array}$ & $\begin{array}{c}\text { II } \\
\text { quartile }\end{array}$ & $\begin{array}{c}\text { III } \\
\text { quartile }\end{array}$ & $\begin{array}{c}\text { IV } \\
\text { quartile }\end{array}$ \\
\hline & (1) & (2) & (3) & (4) & (5) & (6) & (7) & $(8)$ & (9) & $(10)$ \\
\hline wage_av & $\begin{array}{l}37.98 \\
(0.31)\end{array}$ & $\begin{array}{c}-156.20 \\
(-1.37)\end{array}$ & $\begin{array}{l}-5.37 \\
(-0.09)\end{array}$ & $\begin{array}{c}216.80 \\
(0.75)\end{array}$ & $\begin{array}{c}491.30 \\
(1.17)\end{array}$ & $\begin{array}{c}-4.1 \mathrm{e}+07 \\
(-1.23)\end{array}$ & $\begin{array}{c}-4.1 \mathrm{e}+07 \\
(-2.24)\end{array}$ & $\begin{array}{c}-1.6 e+07 \\
(-0.56)\end{array}$ & $\begin{array}{c}-5.3 e+07 \\
(-0.54)\end{array}$ & $\begin{array}{c}2.7 e+08 \\
(1.84)\end{array}$ \\
\hline wage_fund & $\begin{array}{c}-0.89^{* * *} \\
(-4.33)\end{array}$ & $\begin{array}{c}0.79 \\
(1.83)\end{array}$ & $\begin{array}{l}-0.23 \\
(-0.65)\end{array}$ & $\begin{array}{c}-0.33^{* * *} \\
(-5.23)\end{array}$ & $\begin{array}{c}-1.69^{* *} \\
(-2.53)\end{array}$ & $\begin{array}{c}-1.9 \mathrm{e}+05^{* * *} \\
(-7.55)\end{array}$ & $\begin{array}{c}4.5 e+05 \\
(1.88)\end{array}$ & $\begin{array}{c}1.8 \mathrm{e}+0.5 \\
(1.62)\end{array}$ & $\begin{array}{c}-3.6 \mathrm{e}+05 \\
(-1.58)\end{array}$ & $\begin{array}{c}-1.6 \mathrm{e}+05^{* * *} \\
(-2.52)\end{array}$ \\
\hline active & $\begin{array}{c}0.004^{* * *} \\
(4.77)\end{array}$ & $\begin{array}{l}-0.001 \\
(-0.53)\end{array}$ & $\begin{array}{l}0.000 \\
(0.21)\end{array}$ & $\begin{array}{c}0.00^{* * *} \\
(3.98)\end{array}$ & $\begin{array}{c}0.001^{* *} \\
(2.5)\end{array}$ & $\begin{array}{c}929.09 * * * \\
(7.24)\end{array}$ & $\begin{array}{c}-1046.50 \\
(-1.76)\end{array}$ & $\begin{array}{l}-348.5 \\
(-0.98)\end{array}$ & $\begin{array}{c}1227.80^{*} \\
(1.94)\end{array}$ & $\begin{array}{l}768.5^{*} \\
(2.04)\end{array}$ \\
\hline unemployed & $\begin{array}{l}0.003 \\
(1.04)\end{array}$ & $\begin{array}{l}-0.004 \\
(-0.61)\end{array}$ & $\begin{array}{l}-0.001 \\
(-0.36)\end{array}$ & $\begin{array}{l}-0.003 \\
(-0.25)\end{array}$ & $\begin{array}{l}-0.003 \\
(-0.77)\end{array}$ & $\begin{array}{c}679.82 \\
(0.71)\end{array}$ & $\begin{array}{l}-36.44 \\
(-0.03)\end{array}$ & $\begin{array}{c}848.60 \\
(0.65)\end{array}$ & $\begin{array}{c}-2710.00 \\
(-1.57)\end{array}$ & $\begin{array}{l}198.6 \\
(0.15)\end{array}$ \\
\hline unemployed_low & $\begin{array}{c}691.07^{* *} \\
(2.74)\end{array}$ & $\begin{array}{l}155.0^{*} \\
(2.24)\end{array}$ & $\begin{array}{l}-40.89 \\
(-0.54)\end{array}$ & $\begin{array}{c}493.30 \\
(1.53)\end{array}$ & $\begin{array}{c}1003.70^{*} \\
(2.20)\end{array}$ & \begin{tabular}{|c|}
$2.2 \mathrm{e}+08^{* * *}$ \\
$(5.19)$
\end{tabular} & $\begin{array}{c}4.1 \mathrm{e}+07 \\
(1.21)\end{array}$ & $\begin{array}{c}4.8 \mathrm{e}+07^{* *} \\
(2.41)\end{array}$ & $\begin{array}{c}5.1 e+07 \\
(0.48)\end{array}$ & $\begin{array}{c}4.8 \mathrm{e}+08^{* * *} \\
(5.29)\end{array}$ \\
\hline graduates & $\begin{array}{l}-0.004 \\
(-1.19)\end{array}$ & $\begin{array}{l}0.004 \\
(1.05)\end{array}$ & $\begin{array}{l}0.003 \\
(1.61)\end{array}$ & $\begin{array}{l}-0.003 \\
(-0.32)\end{array}$ & $\begin{array}{l}-0.001 \\
(-0.05)\end{array}$ & $\begin{array}{c}-3.4 \mathrm{e}+03^{* *} \\
(-2.31)\end{array}$ & $\begin{array}{c}-1421.1^{* * *} \\
(-4.05)\end{array}$ & $\begin{array}{c}-1168.7 \\
(-1.59)\end{array}$ & $\begin{array}{c}1496.60 \\
(0.46)\end{array}$ & $\begin{array}{l}-4399 \\
(-1.68)\end{array}$ \\
\hline ind_production & $\begin{array}{l}0.002 \\
(1.10)\end{array}$ & $\begin{array}{c}0.0003 \\
(0.41)\end{array}$ & $\begin{array}{c}0.00208^{*} \\
(1.93)\end{array}$ & $\begin{array}{l}0.01^{*} \\
(2.31)\end{array}$ & $\begin{array}{c}0.001 \\
(0.3)\end{array}$ & $\begin{array}{c}459.80^{*} \\
(1.95)\end{array}$ & $\begin{array}{r}-165.70 \\
(-0.72)\end{array}$ & $\begin{array}{c}182.5^{* *} \\
(2.41)\end{array}$ & $\begin{array}{c}1740.00 \\
(1.37)\end{array}$ & $\begin{array}{l}-51.15 \\
(-0.08)\end{array}$ \\
\hline roads_density & $\begin{array}{c}0.20 \\
(0.97)\end{array}$ & $\begin{array}{c}0.08 \\
(0.33)\end{array}$ & $\begin{array}{c}0.08 \\
(0.93)\end{array}$ & $\begin{array}{c}0.13 \\
(0.46)\end{array}$ & $\begin{array}{c}0.39 \\
(0.66)\end{array}$ & $\begin{array}{c}1.9 e+04 \\
(0.40)\end{array}$ & $\begin{array}{c}-2.0 e+04 \\
(-0.36)\end{array}$ & $\begin{array}{c}1.3 e+04 \\
(0.62)\end{array}$ & $\begin{array}{c}-1.8 \mathrm{e}+04 \\
(-0.13)\end{array}$ & $\begin{array}{c}6.3 e+04 \\
(0.63)\end{array}$ \\
\hline border & $\begin{array}{l}-22.04 \\
(-1.00)\end{array}$ & $\begin{array}{l}31.16 \\
(1.64)\end{array}$ & $\begin{array}{c}9.20 \\
(0.64)\end{array}$ & $\begin{array}{l}13.50 \\
(0.52)\end{array}$ & $\begin{array}{c}-106.60 \\
(-1.06)\end{array}$ & $\begin{array}{c}-1.2 \mathrm{e}+07^{*} \\
(-2.00)\end{array}$ & \begin{tabular}{|c|}
$-1.7 e+07^{* * * *}$ \\
$(-3.49)$
\end{tabular} & $\begin{array}{c}3.0 \mathrm{e}+06 \\
(0.93)\end{array}$ & $\begin{array}{c}1.2 \mathrm{e}+06 \\
(-0.11)\end{array}$ & $\begin{array}{c}1.9 \mathrm{e}+07 \\
(0.5)\end{array}$ \\
\hline remaining_years & $\begin{array}{c}23.85^{* *} \\
(2.74)\end{array}$ & $\begin{array}{c}14.89^{* *} \\
(2.58)\end{array}$ & $\begin{array}{c}14.46^{* *} \\
(3.1)\end{array}$ & $\begin{array}{l}27.55^{*} \\
(2.19)\end{array}$ & $\begin{array}{c}35.98^{*} \\
(2.17)\end{array}$ & $\begin{array}{c}2.7 e+06 \\
(1.26)\end{array}$ & $\begin{array}{c}3.6 \mathrm{e}+07^{* *} \\
(2.58)\end{array}$ & $\begin{array}{c}2.9 e+05 \\
(0.71)\end{array}$ & $\begin{array}{c}8.1 \mathrm{e}+07 \\
(1.61)\end{array}$ & $\begin{array}{c}-2.3 e+06 \\
(-0.51)\end{array}$ \\
\hline max_exmpt & $\begin{array}{c}361.33^{* *} \\
(2.34)\end{array}$ & $\begin{array}{l}129.6^{*} \\
(2.03)\end{array}$ & $\begin{array}{l}55.10 \\
(1.02)\end{array}$ & $\begin{array}{c}423.90 \\
(1.74)\end{array}$ & $\begin{array}{c}1120.90^{*} \\
(2.13)\end{array}$ & $\begin{array}{c}3.7 e+07 \\
(0.85)\end{array}$ & $\begin{array}{c}9.8 \mathrm{e}+07 \\
(1.83)\end{array}$ & $\begin{array}{c}2.5 e+07 \\
(0.99)\end{array}$ & $\begin{array}{c}-8.6 \mathrm{e}+07 \\
(-1.20)\end{array}$ & $\begin{array}{c}1.9 \mathrm{e}+08^{*} \\
(2.09)\end{array}$ \\
\hline n_SEZ_firms & $\begin{array}{c}1.49 \\
(0.35)\end{array}$ & $\begin{array}{c}1.75 \\
(0.12)\end{array}$ & $\begin{array}{c}2.96 \\
(0.87)\end{array}$ & $\begin{array}{l}-0.93 \\
(-0.17)\end{array}$ & $\begin{array}{l}-3.46 \\
(-0.51)\end{array}$ & $\begin{array}{c}1.9 e+06 \\
(1.36)\end{array}$ & $\begin{array}{c}2.5 \mathrm{e}+06^{* * *} \\
(3.95)\end{array}$ & $\begin{array}{c}8.5 e+05 \\
(0.83)\end{array}$ & $\mid \begin{array}{c}-5.5 e+05 \\
(-0.27)\end{array}$ & $\begin{array}{c}6.6 e+05 \\
(0.32)\end{array}$ \\
\hline share_foreign & $\begin{array}{c}60.61^{* *} \\
(2.36)\end{array}$ & $\begin{array}{l}-20.09 \\
(-0.59)\end{array}$ & $\begin{array}{l}-22.89 \\
(-1.05)\end{array}$ & $\begin{array}{c}4.55 \\
(0.10)\end{array}$ & $\begin{array}{l}155.60 \\
(1.47)\end{array}$ & $\begin{array}{c}2.5 \mathrm{e}+07^{* * *} \\
(3.23)\end{array}$ & $\begin{array}{c}1.1 e+07 \\
(1.04)\end{array}$ & $\begin{array}{c}7.9 \mathrm{e}+06^{* *} \\
(3.01)\end{array}$ & $\begin{array}{c}-2.2 e+07 \\
(-0.87)\end{array}$ & $\begin{array}{c}2.6 e+07 \\
(1.13)\end{array}$ \\
\hline technology & $\begin{array}{l}18.09 \\
(0.93)\end{array}$ & $\begin{array}{l}-7.58 \\
(-0.95)\end{array}$ & $\begin{array}{l}38.94 \\
(1.15)\end{array}$ & $\begin{array}{r}-119.20 \\
(-1.27) \\
\end{array}$ & $\begin{array}{l}20.35 \\
(0.23)\end{array}$ & $\begin{array}{c}3.0 \mathrm{e}+07^{* *} \\
(2.90)\end{array}$ & $\begin{array}{c}-2.0 \mathrm{e}+06 \\
(-0.72)\end{array}$ & $\begin{array}{c}1.3 e+06 \\
(0.47)\end{array}$ & $\begin{array}{c}-9.9 e+06 \\
(-0.26)\end{array}$ & $\begin{array}{c}9.3 e+07^{* * *} \\
(5.07)\end{array}$ \\
\hline $\begin{array}{l}\text { gini_- } \\
\text { employment }\end{array}$ & $\begin{array}{l}89.78 \\
(1.10)\end{array}$ & $\begin{array}{l}-38.70 \\
(-0.68)\end{array}$ & $\begin{array}{l}-28.91 \\
(-0.84)\end{array}$ & $\begin{array}{l}-18.84 \\
(-0.28)\end{array}$ & $\begin{array}{c}519.50 \\
(1.52)\end{array}$ & - & - & - & - & - \\
\hline gini_investment & - & - & - & - & - & $\begin{array}{c}3.7 e+07 \\
(1.22)\end{array}$ & $\begin{array}{c}-8.3 e+04 \\
(-0.01)\end{array}$ & $\begin{array}{c}-6.1 e+06 \\
(-1.32) \\
\end{array}$ & $\begin{array}{c}3.4 \mathrm{e}+07 \\
(0.72)\end{array}$ & $\begin{array}{c}8.6 \mathrm{e}+07 \\
(0.89)\end{array}$ \\
\hline Constant & $\begin{array}{c}-740.50 * * \\
(-3.09)\end{array}$ & $\begin{array}{c}-110.00 \\
(-1.42)\end{array}$ & $\begin{array}{c}-134.70 \\
(-1.17)\end{array}$ & $\begin{array}{c}-774.50 \\
(-1.44)\end{array}$ & $\begin{array}{c}-1854.90^{* *} \\
(-2.76)\end{array}$ & \begin{tabular}{|c|}
$-1.7 e+08^{* * *}$ \\
$(-2.99)$
\end{tabular} & $\begin{array}{c}-5.2 \mathrm{e}+07 \\
(-1.35)\end{array}$ & $\begin{array}{c}-1.9 e+07 \\
(-0.59)\end{array}$ & $\begin{array}{c}-3.2 \mathrm{e}+06 \\
(-0.03)\end{array}$ & $\begin{array}{c}-4.7 e+08^{* *} \\
(-3.00)\end{array}$ \\
\hline $\mathbf{N}$ & 1,826 & 282 & 416 & 508 & 557 & 1,826 & 292 & 422 & 507 & 542 \\
\hline$R^{2}$ & 0.043 & 0.063 & 0.051 & 0.027 & 0.053 & 0.056 & 0.136 & 0.096 & 0.011 & 0.069 \\
\hline
\end{tabular}

Notes: Table 4 presents estimation results for Models 5 and 6 on the total sub samples of SEZ-hosting counties delimited by quartiles of employment (left part of the table) and investment (right part of the table). Dependent variables are the net number of jobs created by firms operating in the SEZ $i$ in the year $t$ (d_employment) and the net fixed capital formation of these firms (d_investment). Detailed specifications of Models 5 and 6 are discussed in Section 5. Definitions of variables are reported in Table 4. $t$-statistics for coefficient estimates are given in parentheses. Stars denote significance of estimates at the $1 \%(* * *)$, $5 \%\left(^{* *}\right)$ and $10 \%(*)$ levels.

Source: the authors 
Table 5: Estimation results: model estimated on whole sample and subsamples delimited by quartiles of distribution of foreign capital share in employment (left panel) and investment (right panel)

\begin{tabular}{|c|c|c|c|c|c|c|c|c|c|c|}
\hline \multirow{4}{*}{$\begin{array}{l}\text { Specifica- } \\
\text { tion }\end{array}$} & \multicolumn{10}{|c|}{ Dependent variable: } \\
\hline & \multicolumn{5}{|c|}{ d_employment } & \multicolumn{5}{|c|}{$d_{-}$investment } \\
\hline & Total & I quartile & II quartile & III quartile & IV quartile & Total & I quartile & II quartile & III quartile & IV quartile \\
\hline & (1) & (2) & (3) & (4) & (5) & (6) & (7) & (8) & (9) & (10) \\
\hline wage_av & $\begin{array}{l}37.98 \\
(0.31)\end{array}$ & $\begin{array}{l}77.01 \\
(1.5)\end{array}$ & $\begin{array}{c}444.90^{*} \\
(1.96)\end{array}$ & $\begin{array}{c}-288.80 \\
(-0.65)\end{array}$ & $\begin{array}{c}335.40 \\
(0.51)\end{array}$ & $\begin{array}{c}-4.1 e+07 \\
(-1.23)\end{array}$ & $\begin{array}{c}1.7 e+07 \\
(0.88)\end{array}$ & $\begin{array}{c}9.4 \mathrm{e}+06^{* *} \\
(2.32)\end{array}$ & $\begin{array}{c}-1.6 e+08 \\
(-0.98)\end{array}$ & $\begin{array}{c}2.9 \mathrm{e}+08 \\
(1.41)\end{array}$ \\
\hline wage_fund & $\begin{array}{c}-0.89 * * * \\
(-4.33)\end{array}$ & $\begin{array}{l}-1.31 * * \\
(-3.20)\end{array}$ & $\begin{array}{c}-1.01 * * * \\
(-3.70)\end{array}$ & $\begin{array}{c}-0.65^{* * *} \\
(-6.05)\end{array}$ & $\begin{array}{c}-2.98^{* * *} \\
(-3.72)\end{array}$ & $\begin{array}{c}-1.9 \mathrm{e}+05^{* * *} \\
(-7.55)\end{array}$ & $\begin{array}{c}-1.5 e+05 \\
(-1.20)\end{array}$ & $\begin{array}{c}-1.3 e+05 \\
(-1.06)\end{array}$ & $\begin{array}{c}-2.2 \mathrm{e}+05^{* * *} \\
(-6.87)\end{array}$ & $\begin{array}{c}-5.0 \mathrm{e}+05^{* * * *} \\
(-3.74)\end{array}$ \\
\hline active & $\begin{array}{c}0.004^{* * * *} \\
(4.77)\end{array}$ & $\begin{array}{c}0.006^{* * * *} \\
(4.23)\end{array}$ & $\begin{array}{c}0.003^{* * *} \\
(4.7)\end{array}$ & $\begin{array}{c}0.003^{* * *} \\
(5.04)\end{array}$ & $\begin{array}{c}0.013^{* * *} \\
(3.90)\end{array}$ & $\begin{array}{c}929.09 * * * \\
(7.24)\end{array}$ & $\begin{array}{l}993.6 \\
(1.46)\end{array}$ & $\begin{array}{c}5.9 \mathrm{e}+02 \\
(1.5)\end{array}$ & $\begin{array}{c}1046.6^{* * *} \\
(6.14)\end{array}$ & $\begin{array}{c}2183.6^{* * *} \\
(5.54)\end{array}$ \\
\hline unemployed & $\begin{array}{l}0.003 \\
(1.04)\end{array}$ & $\begin{array}{c}-0.013^{* * *} \\
(-4.13)\end{array}$ & $\begin{array}{l}-0.005 \\
(-1.51) \\
\end{array}$ & $\begin{array}{l}0.009 \\
(1.69)\end{array}$ & $\begin{array}{l}-0.007 \\
(-0.34) \\
\end{array}$ & $\begin{array}{c}679.82 \\
(0.71)\end{array}$ & $\begin{array}{c}-3476.3^{*} \\
(-1.89)\end{array}$ & $\begin{array}{c}345.60 \\
(0.44)\end{array}$ & $\begin{array}{c}3375.3^{* * *} \\
(3.56)\end{array}$ & $\begin{array}{c}9615.5^{* *} \\
(-2.32)\end{array}$ \\
\hline $\begin{array}{l}\text { unem- } \\
\text { ployed_low }\end{array}$ & $\begin{array}{c}691.07^{* *} \\
(2.74)\end{array}$ & $\begin{array}{c}115.00 \\
(0.9)\end{array}$ & $\begin{array}{l}55.64 \\
(0.25)\end{array}$ & $\begin{array}{c}1275.00 \\
(1.84)\end{array}$ & $\begin{array}{c}192.70 \\
(0.42)\end{array}$ & \begin{tabular}{|c|}
$2.2 \mathrm{e}+08^{* * * *}$ \\
$(5.19)$
\end{tabular} & $\begin{array}{c}3.5 e+08 \\
(0.94)\end{array}$ & $\begin{array}{c}-7.8 \mathrm{e}+06 \\
(-0.46)\end{array}$ & $\begin{array}{c}2.9 \mathrm{e}+08^{* * * *} \\
(4.09)\end{array}$ & $\begin{array}{c}4.2 \mathrm{e}+07 \\
(0.21)\end{array}$ \\
\hline graduates & $\begin{array}{l}-0.004 \\
(-1.19)\end{array}$ & $\begin{array}{l}-0.002 \\
(-0.39)\end{array}$ & $\begin{array}{l}0.001 \\
(0.22)\end{array}$ & $\begin{array}{l}0.002 \\
(0.17)\end{array}$ & $\begin{array}{l}-0.012 \\
(-0.58)\end{array}$ & $\begin{array}{c}-3.4 \mathrm{e}+03^{* *} \\
(-2.31)\end{array}$ & $\begin{array}{l}-593 \\
(-0.76)\end{array}$ & $\begin{array}{c}-2911.80 \\
(-1.02)\end{array}$ & $\begin{array}{c}-2.5 e+03 \\
(-0.51)\end{array}$ & $\begin{array}{c}-9.4 e+02 \\
(-0.32)\end{array}$ \\
\hline $\begin{array}{l}\text { ind } \\
\text { production }\end{array}$ & $\begin{array}{l}0.002 \\
(1.10) \\
\end{array}$ & $\begin{array}{l}0.001^{*} \\
(1.99) \\
\end{array}$ & $\begin{array}{l}0.002 \\
(1.12) \\
\end{array}$ & $\begin{array}{c}0.004^{* * *} \\
(3.47)\end{array}$ & $\begin{array}{c}0.000 \\
(-0.02) \\
\end{array}$ & $\begin{array}{c}459.80^{*} \\
(1.95) \\
\end{array}$ & $\begin{array}{l}198.6 \\
(1.43) \\
\end{array}$ & $\begin{array}{r}-277.00 \\
(-0.84) \\
\end{array}$ & $\begin{array}{c}1315.4^{* * *} \\
(3.69)\end{array}$ & $\begin{array}{c}-5.0 e+02 \\
(-0.53)\end{array}$ \\
\hline $\begin{array}{l}\text { roads } \\
\text { density }\end{array}$ & $\begin{array}{c}0.20 \\
(0.97)\end{array}$ & $\begin{array}{l}-0.12 \\
(-1.14)\end{array}$ & $\begin{array}{c}0.51 \\
(1.58)\end{array}$ & $\begin{array}{l}-0.067 \\
(-0.12)\end{array}$ & $\begin{array}{l}-0.006 \\
(-0.01)\end{array}$ & $\begin{array}{c}1.9 e+04 \\
(0.40)\end{array}$ & $\begin{array}{c}-7.1 \mathrm{e}+04 \\
(-1.57)\end{array}$ & $\begin{array}{c}2.9 e+04 \\
(0.59)\end{array}$ & $\begin{array}{c}1.8 \mathrm{e}+03 \\
(0.01)\end{array}$ & $\begin{array}{c}-7.7 e+04 \\
(-0.71)\end{array}$ \\
\hline border & $\begin{array}{l}-22.04 \\
(-1.00)\end{array}$ & $\begin{array}{l}13.17 \\
(0.4)\end{array}$ & $\begin{array}{l}86.94^{*} \\
(2.08)\end{array}$ & $\begin{array}{c}-100.70 \\
(-1.60)\end{array}$ & $\begin{array}{l}94.60 \\
(0.94)\end{array}$ & $\begin{array}{c}-1.2 \mathrm{e}+07^{*} \\
(-2.00)\end{array}$ & $\begin{array}{c}8.1 e+05 \\
(0.15)\end{array}$ & $\begin{array}{c}4.3 e+05 \\
(0.06)\end{array}$ & $\begin{array}{c}-1.8 \mathrm{e}+07 \\
(-0.84)\end{array}$ & $\begin{array}{c}-1.4 \mathrm{e}+07 \\
(-0.82)\end{array}$ \\
\hline $\begin{array}{l}\text { remain- } \\
\text { ing_years }\end{array}$ & $\begin{array}{c}23.85^{* *} \\
(2.74)\end{array}$ & $\begin{array}{c}22.70^{* * *} \\
(2.99)\end{array}$ & $\begin{array}{c}6.18 \\
(0.52)\end{array}$ & $\begin{array}{c}35.44 * * * \\
(3.61)\end{array}$ & $\begin{array}{l}39.54 \\
(1.43)\end{array}$ & $\begin{array}{c}2.7 e+06 \\
(1.26)\end{array}$ & $\begin{array}{c}3.2 \mathrm{e}+06^{* * *} \\
(4.43)\end{array}$ & $\begin{array}{c}1.3 e+06 \\
(1.23)\end{array}$ & $\begin{array}{c}1.9 e+06 \\
(0.31)\end{array}$ & $\begin{array}{c}5.5 e+06 \\
(1.29)\end{array}$ \\
\hline $\begin{array}{l}\max _{-} \\
\text {exmpt }\end{array}$ & $\begin{array}{c}361.33^{* *} \\
(2.34)\end{array}$ & $\begin{array}{c}136.80 \\
(1.1)\end{array}$ & $\begin{array}{c}458.30^{*} \\
(2.35)\end{array}$ & $\begin{array}{c}656.90 \\
(0.98)\end{array}$ & $\begin{array}{c}548.40 \\
(1.12)\end{array}$ & $\begin{array}{c}3.7 e+07 \\
(0.85)\end{array}$ & $\begin{array}{c}3.4 \mathrm{e}+07 \\
(0.89)\end{array}$ & $\begin{array}{c}-1.7 e+07 \\
(-0.50)\end{array}$ & $\begin{array}{c}5.8 e+07 \\
(0.67)\end{array}$ & $\begin{array}{c}2.0 \mathrm{e}+08^{* *} \\
(2.28)\end{array}$ \\
\hline n_SEZ_firms & $\begin{array}{c}1.49 \\
(0.35)\end{array}$ & $\begin{array}{c}4.19 \\
(1.86)\end{array}$ & $\begin{array}{c}10.00^{*} \\
(2.3)\end{array}$ & $\begin{array}{l}-2.48 \\
(-0.37)\end{array}$ & $\begin{array}{c}9.91 \\
(1.01) \\
\end{array}$ & $\begin{array}{c}1.9 e+06 \\
(1.36)\end{array}$ & $\begin{array}{c}-3.9 e+05 \\
(-0.44)\end{array}$ & $\begin{array}{c}1.4 \mathrm{e}+06^{* * *} \\
(4.87)\end{array}$ & $\begin{array}{c}-9.8 e+05 \\
(-0.40)\end{array}$ & $\begin{array}{c}9.5 \mathrm{e}+06^{* *} \\
(3.08)\end{array}$ \\
\hline $\begin{array}{l}\text { share } \\
\text { foreign }\end{array}$ & $\begin{array}{c}60.61^{* *} \\
(2.36)\end{array}$ & $\begin{array}{l}48.26 \\
(0.71)\end{array}$ & $\begin{array}{l}41.64 \\
(0.73)\end{array}$ & $\begin{array}{c}-130.10 \\
(-1.18)\end{array}$ & $\begin{array}{l}33.87 \\
(0.31)\end{array}$ & \begin{tabular}{|c|}
$2.5 \mathrm{e}+07^{* * * *}$ \\
$(3.23)$
\end{tabular} & $\begin{array}{c}-1.3 e+05 \\
(-0.00)\end{array}$ & $\begin{array}{c}1.8 \mathrm{e}+07 \\
(1.48)\end{array}$ & $\begin{array}{c}-5.4 \mathrm{e}+07 \\
(-1.30)\end{array}$ & $\begin{array}{c}-6.9 e+06 \\
(-0.43)\end{array}$ \\
\hline technology & $\begin{array}{l}18.09 \\
(0.93)\end{array}$ & $\begin{array}{l}-14.53 \\
(-0.72) \\
\end{array}$ & $\begin{array}{l}22.13 \\
(0.29)\end{array}$ & $\begin{array}{c}26.87 \\
(0.3)\end{array}$ & $\begin{array}{l}16.08 \\
(0.17)\end{array}$ & $\begin{array}{c}3.0 \mathrm{e}+07^{* *} \\
(2.90)\end{array}$ & $\begin{array}{c}-7.3 e+06^{* * *} \\
(-3.87)\end{array}$ & $\begin{array}{c}6.2 e+02 \\
(0.37)\end{array}$ & $\begin{array}{c}6.6 e+07 \\
(1.56)\end{array}$ & $\begin{array}{c}1.1 \mathrm{e}+07 \\
(0.45)\end{array}$ \\
\hline $\begin{array}{l}\text { gini_- } \\
\text { employment }\end{array}$ & $\begin{array}{l}89.78 \\
(1.10)\end{array}$ & $\begin{array}{l}-49.16 \\
(-0.95)\end{array}$ & $\begin{array}{l}-58.75 \\
(-0.58)\end{array}$ & $\begin{array}{c}298.90 \\
(1.08)\end{array}$ & $\begin{array}{c}225.40 \\
(1.66)\end{array}$ & - & - & - & - & - \\
\hline $\begin{array}{l}\text { gini_ } \\
\text { investment }\end{array}$ & - & - & - & - & - & \begin{tabular}{|c|}
$3.7 e+07$ \\
$(1.22)$ \\
\end{tabular} & $\begin{array}{c}1.0 \mathrm{e}+07 \\
(1.29) \\
\end{array}$ & $\begin{array}{c}4.6 e+06 \\
(0.41)\end{array}$ & $\begin{array}{c}9.6 \mathrm{e}+07 \\
(1.62)\end{array}$ & $\begin{array}{c}5.2 \mathrm{e}+07 \\
(1.24)\end{array}$ \\
\hline Constant & $\begin{array}{c}-740.50^{* *} \\
(-3.09)\end{array}$ & $\begin{array}{c}-366.70 * * \\
(-2.78)\end{array}$ & $\begin{array}{c}-772.00^{* *} \\
(-3.15)\end{array}$ & $\begin{array}{c}-846.90 \\
(-1.25)\end{array}$ & $\begin{array}{c}-1125.50 \\
(-1.20)\end{array}$ & $\begin{array}{c}-1.7 \mathrm{e}+08^{* * * *} \\
(-2.99)\end{array}$ & $\begin{array}{c}-5.8 \mathrm{e}+07^{* *} \\
(-2.28)\end{array}$ & $\begin{array}{c}-8.6 \mathrm{e}+07^{* *} \\
(-2.62)\end{array}$ & $\begin{array}{c}-1.3 e+07 \\
(-0.08)\end{array}$ & $\begin{array}{c}-3.6 \mathrm{e}+08^{*} \\
(-1.82)\end{array}$ \\
\hline $\mathbf{N}$ & 1,826 & 513 & 291 & 499 & 435 & 1,826 & 487 & 320 & 519 & 437 \\
\hline$R^{2}$ & 0.043 & 0.047 & 0.084 & 0.053 & 0.054 & 0.056 & 0.043 & 0.146 & 0.040 & 0.113 \\
\hline
\end{tabular}

Notes: Table 5 presents estimation results for Models 5 and 6 on the total subsamples of SEZ-hosting counties delimited by quartiles of foreign capital share in employment (left part of the table) and investment (right part of the table). Dependent variables are the net number of jobs created by firms operating in the SEZ $i$ in the year $t\left(d_{-}\right.$employment) and the net fixed capital formation of these firms (d_investment). Detailed specifications of Models 5 and 6 are discussed in Section 5. Definitions of variables are reported in Table 4. $t$-statistics for coefficient estimates are given in parentheses. Stars denote significance of estimates at the $1 \%\left({ }^{* *}\right), 5 \%\left({ }^{* *}\right)$ and $10 \%\left({ }^{*}\right)$ levels.

Source: the authors 
Table 6: Estimation results: model estimated on whole sample and subsamples delimited by quartiles of distribution of medium- and high-tech firms' share in employment (left panel) and investment (right panel)

\begin{tabular}{|c|c|c|c|c|c|c|c|c|c|c|}
\hline \multirow{4}{*}{ Specification } & \multicolumn{10}{|c|}{ Dependent variable: } \\
\hline & \multicolumn{5}{|c|}{ d_employment } & \multicolumn{5}{|c|}{ d_investment } \\
\hline & Total & $\begin{array}{c}\text { I } \\
\text { quartile }\end{array}$ & $\begin{array}{c}\text { II } \\
\text { quartile }\end{array}$ & \begin{tabular}{|c|} 
III \\
quartile
\end{tabular} & $\begin{array}{c}\text { IV } \\
\text { quartile }\end{array}$ & Total & $\begin{array}{c}\text { I } \\
\text { quartile }\end{array}$ & $\begin{array}{c}\text { II } \\
\text { quartile }\end{array}$ & $\begin{array}{c}\text { III } \\
\text { quartile }\end{array}$ & $\begin{array}{c}\text { IV } \\
\text { quartile }\end{array}$ \\
\hline & (1) & (2) & (3) & (4) & $(5)$ & (6) & (7) & $(8)$ & (9) & (10) \\
\hline wage_av & $\begin{array}{l}37.98 \\
(0.31)\end{array}$ & $\begin{array}{l}99.73 \\
(1.63)\end{array}$ & $\begin{array}{c}-738.90 \\
(-1.04)\end{array}$ & $\begin{array}{l}-74.93 \\
(-0.17)\end{array}$ & $\begin{array}{l}247.70 \\
(0.86)\end{array}$ & $\begin{array}{c}-4.1 \mathrm{e}+07 \\
(-1.23)\end{array}$ & $\begin{array}{c}3.6+07 \\
(1.83)\end{array}$ & $\begin{array}{l}1.5 e+08 \\
(-0.74)\end{array}$ & $\begin{array}{c}-7.0 \mathrm{e}+07 \\
(-1.03)\end{array}$ & $\begin{array}{c}2.4 \mathrm{e}+08^{* * * *} \\
(3.82)\end{array}$ \\
\hline wage_fund & $\begin{array}{c}-0.89^{* * *} \\
(-4.33)\end{array}$ & $\begin{array}{c}-0.55^{* * *} \\
(-5.44)\end{array}$ & $\begin{array}{l}-3.26 \\
(-0.93)\end{array}$ & $\begin{array}{l}-2.08 \\
(-1.66)\end{array}$ & $\begin{array}{l}-1.51^{* *} \\
(-3.03)\end{array}$ & $\begin{array}{c}-1.9 \mathrm{e}+05^{* * * *} \\
(-7.55)\end{array}$ & $\begin{array}{c}-1.2 \mathrm{e}+05^{* *} \\
(-2.87)\end{array}$ & $\begin{array}{c}3.5 e+05 \\
(0.42)\end{array}$ & $\begin{array}{c}-5.6 \mathrm{e}+05^{* * * *} \\
(-3.41)\end{array}$ & $\begin{array}{c}-4.2 \mathrm{e}+05^{* *} \\
(-3.29)\end{array}$ \\
\hline active & $\begin{array}{c}0.004^{* * *} \\
(4.77)\end{array}$ & $\begin{array}{c}0.003^{* * *} \\
(5.84)\end{array}$ & $\begin{array}{l}0.017 \\
(1.72)\end{array}$ & $\begin{array}{l}0.008 \\
(1.81)\end{array}$ & $\begin{array}{c}0.006^{* *} \\
(3.26)\end{array}$ & $\begin{array}{c}929.09^{* * *} \\
(7.24)\end{array}$ & $\begin{array}{c}729.7^{* * *} \\
(3.46)\end{array}$ & $\begin{array}{c}2.8 e+03 \\
(0.73)\end{array}$ & $\begin{array}{c}2579.3^{* * *} \\
(4.58)\end{array}$ & $\begin{array}{c}1307.5^{* *} \\
(2.68)\end{array}$ \\
\hline unemployed & $\begin{array}{l}0.003 \\
(1.04)\end{array}$ & $\begin{array}{l}0.001 \\
(0.42)\end{array}$ & $\begin{array}{l}-0.034 \\
(-1.87)\end{array}$ & $\begin{array}{l}-0.003 \\
(-0.23)\end{array}$ & $\begin{array}{l}-0.013 \\
(-1.68)\end{array}$ & $\begin{array}{l}679.82 \\
(0.71)\end{array}$ & $\begin{array}{c}-2.5 e+03 \\
(-1.67)\end{array}$ & $\begin{array}{c}-8.1 e+03 \\
(-0.90)\end{array}$ & $\begin{array}{l}-3119.1 \\
(-1.80)\end{array}$ & $\begin{array}{c}5.81 \\
(0.00)\end{array}$ \\
\hline $\begin{array}{l}\text { unemployed_ } \\
\text { low }\end{array}$ & $\begin{array}{c}691.07^{* * *} \\
(2.74)\end{array}$ & $\begin{array}{c}-162.00 \\
(-1.10)\end{array}$ & $\begin{array}{l}404.50 \\
(0.54)\end{array}$ & $\begin{array}{l}815.10 \\
(1.74)\end{array}$ & $\begin{array}{c}1682.00^{* *} \\
(2.96)\end{array}$ & $\begin{array}{c}2.2 \mathrm{e}+08^{* * *} \\
(5.19)\end{array}$ & $\begin{array}{c}-1.2 \mathrm{e}+08 \\
(-0.84)\end{array}$ & $\begin{array}{c}2.0 \mathrm{e}+08 \\
(2.02)\end{array}$ & $\begin{array}{c}2.3 e+08 \\
(1.72)\end{array}$ & $\begin{array}{c}6.1 \mathrm{e}+08^{* * *} \\
(3.84)\end{array}$ \\
\hline graduates & $\begin{array}{l}-0.004 \\
(-1.19)\end{array}$ & $\begin{array}{c}-0.02^{* * *} \\
(-4.11)\end{array}$ & $\begin{array}{c}0.02 \\
(0.81)\end{array}$ & $\begin{array}{l}0.01 \\
(0.4)\end{array}$ & $\begin{array}{l}0.01 \\
(0.79)\end{array}$ & $\begin{array}{c}-3.4 \mathrm{e}+03^{* *} \\
(-2.31)\end{array}$ & $\begin{array}{c}-2.1 \mathrm{e}+03 \\
(-0.78)\end{array}$ & $\begin{array}{c}-9.2 \mathrm{e}+02 \\
(-0.23)\end{array}$ & $\begin{array}{c}-4278.2^{* *} \\
(-2.68)\end{array}$ & $\begin{array}{c}3.6 \mathrm{e}+03 \\
(0.84)\end{array}$ \\
\hline $\begin{array}{l}\text { ind_ } \\
\text { production }\end{array}$ & $\begin{array}{l}0.002 \\
(1.10)\end{array}$ & $\begin{array}{c}-0.00009 \\
(-0.14)\end{array}$ & $\begin{array}{l}0.001 \\
(0.2)\end{array}$ & $\begin{array}{c}0.003 \\
(1.8)\end{array}$ & $\begin{array}{l}0.002 \\
(0.55)\end{array}$ & $\begin{array}{l}459.80^{*} \\
(1.95)\end{array}$ & $\begin{array}{c}3.7 e+01 \\
(0.12)\end{array}$ & $\begin{array}{c}-8.1 e+01 \\
(-0.06)\end{array}$ & $\begin{array}{c}466.9^{* *} \\
(2.41)\end{array}$ & $\begin{array}{c}1.2 \mathrm{e}+02 \\
(0.15)\end{array}$ \\
\hline $\begin{array}{l}\text { roads } \\
\text { density }\end{array}$ & $\begin{array}{l}0.20 \\
(0.97)\end{array}$ & $\begin{array}{l}-0.08 \\
(-0.65)\end{array}$ & $\begin{array}{l}-0.98^{* *} \\
(-2.73)\end{array}$ & $\begin{array}{c}0.12 \\
(0.29)\end{array}$ & $\begin{array}{l}-0.06 \\
(-0.11)\end{array}$ & $\begin{array}{c}1.9 e+04 \\
(0.40)\end{array}$ & $\begin{array}{c}-7.8 \mathrm{e}+04^{* *} \\
(-2.69)\end{array}$ & $\begin{array}{c}-3.7 e+05 \\
(-1.17)\end{array}$ & $\begin{array}{c}4.4 \mathrm{e}+04 \\
(0.64)\end{array}$ & $\begin{array}{c}-1.8 \mathrm{e}+05 \\
(-1.73)\end{array}$ \\
\hline border & $\begin{array}{l}-22.04 \\
(-1.00)\end{array}$ & $\begin{array}{l}-22.34 \\
(-0.80)\end{array}$ & $\begin{array}{l}161.40 \\
(1.47)\end{array}$ & $\begin{array}{l}8.56 \\
(0.21)\end{array}$ & $\begin{array}{r}-118.20 \\
(-1.57)\end{array}$ & $\begin{array}{c}-1.2 \mathrm{e}+07^{*} \\
(-2.00)\end{array}$ & $\begin{array}{c}-7.9 e+06 \\
(-0.91)\end{array}$ & $\begin{array}{c}-3.1 \mathrm{e}+07 \\
(-1.47)\end{array}$ & $\begin{array}{c}-2.4 \mathrm{e}+07^{* *} \\
(-2.62)\end{array}$ & $\begin{array}{c}-1.9 \mathrm{e}+07 \\
(-0.95)\end{array}$ \\
\hline $\begin{array}{l}\text { remaining } \\
\text { years }\end{array}$ & $\begin{array}{c}23.85^{* *} \\
(2.74)\end{array}$ & $\begin{array}{c}19.09^{* * *} \\
(4.1)\end{array}$ & $\begin{array}{c}56.80^{* *} \\
(2.66)\end{array}$ & $\begin{array}{l}26.02 \\
(1.23)\end{array}$ & $\begin{array}{c}42.82^{* * *} \\
(3.67)\end{array}$ & $\begin{array}{c}2.7 e+06 \\
(1.26)\end{array}$ & $\begin{array}{c}8.6 \mathrm{e}+06^{* *} \\
(2.80)\end{array}$ & $\begin{array}{c}-1.2 \mathrm{e}+07 \\
(-0.47)\end{array}$ & $\begin{array}{c}9.9 \mathrm{e}+05 \\
(0.23)\end{array}$ & $\begin{array}{c}1.1 \mathrm{e}+06 \\
(0.85)\end{array}$ \\
\hline max_exmpt & $\begin{array}{c}361.33^{* *} \\
(2.34)\end{array}$ & $\begin{array}{c}413.90^{* * * *} \\
(4.86)\end{array}$ & $\begin{array}{c}774.60 \\
(1.58)\end{array}$ & $\begin{array}{c}-253.40 \\
(-0.81)\end{array}$ & $\begin{array}{c}1301.80^{* * *} \\
(2.85)\end{array}$ & $\begin{array}{c}3.7 e+07 \\
(0.85)\end{array}$ & $\begin{array}{c}1.1 \mathrm{e}+08 \\
(1.56)\end{array}$ & $\begin{array}{c}1.5 \mathrm{e}+08 \\
(1.24)\end{array}$ & $\begin{array}{c}-1.1 \mathrm{e}+06 \\
(-0.01)\end{array}$ & $\begin{array}{c}1.2 \mathrm{e}+08 \\
(0.99)\end{array}$ \\
\hline n_SEZ_firms & $\begin{array}{c}1.49 \\
(0.35)\end{array}$ & $\begin{array}{l}10.47 \\
(1.19)\end{array}$ & $\begin{array}{l}-15.21 \\
(-1.51)\end{array}$ & $\begin{array}{l}-2.84 \\
(-0.37)\end{array}$ & $\begin{array}{c}9.69 \\
(1.44)\end{array}$ & $\begin{array}{c}1.9 \mathrm{e}+06 \\
(1.36)\end{array}$ & $\begin{array}{c}-9.2 \mathrm{e}+05 \\
(-0.32)\end{array}$ & $\begin{array}{c}-2.8 \mathrm{e}+06 \\
(-1.42)\end{array}$ & $\begin{array}{c}-1.6 e+06 \\
(-0.58)\end{array}$ & $\begin{array}{c}8.8 \mathrm{e}+06^{* * * *} \\
(4.77)\end{array}$ \\
\hline $\begin{array}{l}\text { share } \\
\text { foreign }\end{array}$ & $\begin{array}{l}60.61^{* *} \\
(2.36)\end{array}$ & $\begin{array}{l}42.56^{*} \\
(1.94)\end{array}$ & $\begin{array}{l}-79.60 \\
(-0.53)\end{array}$ & $\begin{array}{l}67.07 \\
(1.23)\end{array}$ & $\begin{array}{l}-51.23 \\
(-0.94)\end{array}$ & $\begin{array}{c}2.5 \mathrm{e}+07^{* * *} \\
(3.23)\end{array}$ & $\begin{array}{c}1.1 e+07 \\
(1.04)\end{array}$ & $\begin{array}{c}7.9 \mathrm{e}+06^{* *} \\
(3.01)\end{array}$ & $\begin{array}{c}-2.2 e+07 \\
(-0.87)\end{array}$ & $\begin{array}{c}2.6 \mathrm{e}+07 \\
(1.13)\end{array}$ \\
\hline technology & $\begin{array}{l}18.09 \\
(0.93)\end{array}$ & $\begin{array}{l}43.28 \\
(0.76)\end{array}$ & $\begin{array}{l}-60.56 \\
(-0.10)\end{array}$ & $\begin{array}{c}-217.00 \\
(-1.61)\end{array}$ & $\begin{array}{l}161.9 \\
(1.46)\end{array}$ & $\begin{array}{c}3.0 \mathrm{e}+07^{* *} \\
(2.90)\end{array}$ & $\begin{array}{c}6.2 \mathrm{e}+07 \\
(0.77)\end{array}$ & $\begin{array}{c}-6.7 e+07 \\
(-0.50)\end{array}$ & \begin{tabular}{|c|}
$5.4 \mathrm{e}+07^{* * *}$ \\
$(3.52)$
\end{tabular} & $\begin{array}{c}7.5 \mathrm{e}+07^{* * * *} \\
(4.70)\end{array}$ \\
\hline $\begin{array}{l}\text { gini } \\
\text { employment }\end{array}$ & $\begin{array}{l}89.78 \\
(1.10)\end{array}$ & $\begin{array}{l}16.91 \\
(0.21)\end{array}$ & $\begin{array}{l}421.60 \\
(1.22)\end{array}$ & $\begin{array}{l}-94.22 \\
(-0.35)\end{array}$ & $\begin{array}{l}323.3^{*} \\
(1.92)\end{array}$ & - & - & - & - & - \\
\hline $\begin{array}{l}\text { gini_ } \\
\text { investment }\end{array}$ & - & - & - & - & - & $\begin{array}{c}3.7 e+07 \\
(1.22)\end{array}$ & $\begin{array}{c}2.8 e+07 \\
(0.57)\end{array}$ & $\begin{array}{c}-5.1 \mathrm{e}+07 \\
(-1.64)\end{array}$ & $\begin{array}{c}6.6 e+07 \\
(0.77\end{array}$ & $\begin{array}{c}2.5 \mathrm{e}+07 \\
(1.21)\end{array}$ \\
\hline Constant & $\begin{array}{c}-740.50^{* * *} \\
(-3.09)\end{array}$ & $\begin{array}{c}-424.80^{* * *} \\
(-3.68)\end{array}$ & $\begin{array}{c}-532.00 \\
(-0.60) \\
\end{array}$ & $\begin{array}{c}-279.40 \\
(-0.41)\end{array}$ & $\begin{array}{c}-1880.50^{* * * *} \\
(-4.81)\end{array}$ & $\begin{array}{c}-1.7 \mathrm{e}+08^{* * * *} \\
(-2.99)\end{array}$ & $\begin{array}{c}1.1 e+08 \\
(-1.97)\end{array}$ & $\begin{array}{c}1.4 \mathrm{e}+08 \\
(1.03)\end{array}$ & $\begin{array}{c}-3.3 e+07 \\
(-0.34)\end{array}$ & $\begin{array}{c}-4.9 \mathrm{e}+08^{* * *} \\
(-4.80)\end{array}$ \\
\hline $\mathbf{N}$ & 1,826 & 693 & 100 & 530 & 440 & 1,826 & 693 & 100 & 530 & 440 \\
\hline$R^{2}$ & 0.043 & 0.052 & 0.122 & 0.061 & 0.065 & 0.056 & 0.009 & 0.385 & 0.084 & 0.334 \\
\hline
\end{tabular}

Notes: Table 6 presents estimation results for Models 5 and 6 on the total subsamples of SEZ-hosting counties delimited by quartiles of distribution of medium- and high-tech firms' share in employment (left part of the table) and investment (right part of the table). Dependent variables are the net number of jobs created by firms operating in the SEZ $i$ in the year $t$ ( $d$ _employment) and the net fixed capital formation of these firms ( $d_{-}$investment). Detailed specifications of Models 5 and 6 are discussed in Section 5. Definitions of variables are reported in Table 4. $t$-statistics for coefficient estimates are given in parentheses. Stars denote significance of estimates at the $1 \%\left({ }^{* *}\right), 5 \%(* *)$ and $10 \%\left({ }^{*}\right)$ levels.

Source: the authors 
- In turn, the number of unemployed persons with primary education has a significant impact on investment and employment growth only in SEZ with highest technological advancement. It seems to be counterintuitive; however, it is worth noting that firms with a high-tech profile do not necessarily employ highly educated people. Moreover, highly skilled workers may be more mobile, while low-skilled workers need to be sourced locally.

- The planned lifetime of a SEZ scheme and the maximum tax exemption are of significance for employment growth irrespective of SEZ technological advancement.

- $\quad$ The number of firms located in a particular SEZ has a significant positive impact on firms' development only in SEZ with above-median technological advancement. This may indicate that the agglomeration effect plays an important role only if firms represent a relatively high average technological level.

\section{Conclusions and Policy Implications}

We estimated a set of panel data models of capital outlays and employment in SEZ-based firms for the years 2003-2015 to investigate why some SEZ in Poland attract more investment and create more jobs than others. The factors behind the varying degree of SEZ success in attracting investors and creating jobs were divided into two groups: regional characteristics and SEZ-specific factors. The main conclusions are as follows:

(i) Both employment and investment growth in SEZ are affected by the labour market characteristics of the SEZ-hosting county: it is higher in SEZ located in counties with high labour participation rates and low wage funds (i.e., the product of employment and average wage). This effect is statistically significant and stronger for firms located in SEZ of above-median size. On the other hand, the average wage level has no significant impact on SEZ development. We interpret this as an indication that regional labour availability matters more for employment and investment growth in SEZ than labour costs. Investors choose zones located in counties with high labour participation rates and, only among them, those with the lowest average wages.

(ii) Employment and investment growth of SEZ is higher in zones hosted by counties with available low-skilled labour. The impact is higher for SEZ with the highest average technological advancement and above-median share of foreign capital and SEZ size. In our opinion, this indicates that an important factor determining the development of a SEZ is the regional availability of low-skilled labour, not high-skilled labour, as the latter is much more mobile, and therefore its unavailability in the county does not limit the development of companies in the zone. 
(iii) Neither the number nor the concentration of firms within a zone have a significant impact on employment and investment growth of SEZ-located firms. By contrast, there is some evidence of positive effects of firms' clustering -in terms of both FDI and technological advancement.

(iv) The planned lifetime of a SEZ known in the year $t$ has a positive and statistically significant impact on SEZ development in terms of employment and - for some specifications - investment. On the other hand, the maximum tax exemption level seems not to affect the rate of employment and investment growth of SEZ (its impact is not robust to changes in specifications). We interpret this as an indication that the uncertainty regarding total tax benefits that investors could expect from their presence in the zones hinders SEZ development. This is especially true for fastgrowing SEZ and those which attract technologically advanced FDIs. In contrast, differences in generosity of tax incentives across zones and in time have no significant effect on their relative attractiveness.

Based on the obtained results, one may formulate some policy-relevant implications.

First of all, regionally targeted incentive schemes based on tax exemptions can work only when there is no labour shortage, which calls for structural reforms aimed at promoting labour participation in the targeted regions.

Secondly, while setting up location-based investment tax incentives, their stability and predictability may be far more important for their success than the size of the tax exemption itself.

Thirdly, even if SEZ meet their main policy goal, i.e., attract investment to regions with untapped unskilled labour, they do not necessarily have to promote clusters and agglomeration formation. Spillover benefits from clustering may require a different set of policies.

\section{References}

Aggarwal, A. (2006). Performance of Export Processing Zones: A Comparative Analysis of India, Sri Lanka and Bangladesh, Journal of Instaflag Institute, 30(1).

Aggarwal, A. (2010). Economic Impacts of SEZ: Theoretical Approaches and Analysis of Newly Notified SEZ in India. Munich Personal RePEc Archive. MPRA Paper No. 20902.

Billings, S. (2009). Do Enterprise Zones Work? An Analysis at the Borders. Public Finance Review, 37(1), 68-93, https://doi.org/10.1177/1091142108321238

Bondonio, D., Engberg, J. (2000). Enterprise Zones and Local Employment: Evidence from States' Programs, Regional Science and Urban Economics, 30(5), 519-549, https://doi.org/10.1016/s0166-0462(00)00042-9 
Cieslewicz, W. (2009). Regionalna pomoc publiczna jako instrument aktywizacji gospodarczejprzypadek specjalnych stref ekonomicznych w Polsce. Nierownosci spoleczne a wzrost gospodarczy. Uwarunkowania instytucjonalne, 15, 318-333.

Ciżkowicz, P., Kowalczuk, M., Rzońca, A. (2016). Heterogeneous Determinants of Local Unemployment in Poland. Post-Communist Economies, 28(4), 487-519, https://doi.org/10.1080/14631377.2016.1226784

Ciżkowicz, P., Ciżkowicz-Pękała, M., Pękała, P., et al. (2016). The Effects of Special Economic Zones on Employment and Investment: A Spatial Panel Modelling Perspective. Journal of Economic Geography, 17(3), 571-605, https://doi.org/10.1093/jeg/lbw028

Crozet, M., Mayer, T., Mucchielli, J.-L. (2004). How Do Firms Agglomerate? A Study of FDI in France. Regional Science and Urban Economics, 34(1), 27-54, https://doi.org/10.1016/s0166-0462(03)00010-3

de Mooij, R. A., Enderveen, S. (2003). Taxation and Foreign Direct Investment: A Synthesis of Empirical Research. International Tax and Public Finance, 10, 673-693.

Devereux, M., Griffith, R., Simpson, H. (2007). Firm Location Decisions, Regional Grants and Agglomeration Externalities. Journal of Public Economics, 91(3-4), 413-435, https://doi.org/10.1016/j.jpubeco.2006.12.002

Driscoll, J. C., Kraay, A. (1998). Consistent Covariance Matrix Estimation with Spatially Dependent Panel Data. The Review of Economics and Statistics, 80(4), 549-560, https://doi.org/10.1162/003465398557825

Duranton, G., Gobillon, L., Overman, H. (2011). Assessing the Effect of Local Taxation Using Microgeographic Data. Economic Journal, 121(555), 1017-1046, https://doi.org/10.1111/j.1468-0297.2011.02439.x

Duranton, G., Puga, D. (2001). Nursery Cities. Urban Diversity, Process Innovation, and the Life Cycle of Products. American Economic Review, 91(5), 1454-1477, https://doi.org/10.1257/ aer.91.5.1454

Engman, M., Onodera, O., Pinali, E. (2007). Export Processing Zones: Past and Future Role in Trade and Development. OECD. Trade Policy Working Paper No. 53, https://doi.org/10.1787/035168776831

Farole, T. (2011). Special Economic Zones in Africa: Comparing Performance and Learning from Global Experience. Washington, DC: World Bank.

Hausman, J. A., Taylor, W. E. (1981). Panel Data and Unobservable Individual Effects. Econometrica, 49(6), 1377-1398, https://doi.org/10.2307/1911406

Head, K., Mayer, T. (2004). Market Potential and the Location of Japanese Firms. Review of Economics and Statistics, 86(4), 959-972, https://doi.org/10.1162/0034653043125257

Head, K., Ries, J., Swenson, D. (1999). Attracting Foreign Manufacturing: Investment Promotion and Agglomeration. Regional Science and Urban Economics, 29(2), 197-218, https://doi.org/10.1016/s0166-0462(98)00029-5 
Hoechle, D. (2006). XTSCC: Stata Module to Calculate Robust Standard Errors for Panels with Cross-sectional Dependence. Statistical Software Components S456787. Boston College Department of Economics.

Mayer, T., Mayneris, F., Py, L. (2013). The Impact of Urban Enterprise Zones on Establishment Location Decisions: Evidence from French ZFUs. Banque de France. Working Paper No. 458, https://doi.org/10.2139/ssrn.2346227

Pesaran, M. H. (2004). General Diagnostic Tests for Cross Section Dependence in Panels. Cambridge Working Papers in Economics No. 0435.

Pesaran, M. H., Smith, R. (1995). Estimating Long-run Relationships from Dynamic Heterogeneous Panels. Journal of Econometrics, 68(1), 79-113, https://doi. org/10.1016/0304-4076(94)01644-f

Rathelot, R., Sillard, P. (2008). The Importance of Local Corporate Taxes in Business Location Decisions: Evidence from French Micro Data. The Economic Journal, 118(527), 449-514, https://doi.org/10.1111/j.1468-0297.2007.02131.x

Rolfe, R. J., Woodward, D., Kagira, B. (2004). Footloose and Tax Free: Incentive Preferences in Kenyan Export Processing Zones. South African Journal of Economics, 72(4), 784-807, https://doi.org/10.1111/j.1813-6982.2004.tb00134.x

Schrank, A. (2001). Export Processing Zones: Free Market Islands or Bridges to Structural Transformation? Development Policy Review, 19(2), 223-242, https://doi. org/10.1111/1467-7679.00132

Trojak, A., Wiedermann, K. (2009). Specjalne strefy ekonomiczne i strefy przemyslowe w ksztaltowaniu rozwoju gospodarczego regionow na przykladzie Polski i Czech. Prace Komisji Geografii Przemyslu PTG, 12, 133-143.

Watson, P. (2001). Export Processing Zones: Has Africa Missed the Boat? Not Yet! World Bank. Africa Region Working Paper Series No. 17.

World Bank (2017). Special Economic Zones an Operational Review of Their Impacts. Washington, DC.: World Bank.

Zeng, D. Z. (2015). Global Experiences with Special Economic Zones with a Focus on China and Africa. World Bank. Policy Research Working Paper No. 7240, https://doi.org/10.1596/1813-9450-7240 


\section{Online Appendix}

Table A1. Maximum tax exemptions ('regional aid intensities') for regions in Poland

\begin{tabular}{|c|c|c|c|c|c|c|c|c|c|c|c|c|c|c|c|c|c|c|}
\hline & 2003 & 2004 & 2005 & 2006 & 2007 & 2008 & 2009 & 2010 & 2011 & 2012 & 2013 & 2014 & 2015 & 2016 & 2017 & 2018 & 2019 & 2020 \\
\hline lubelskie voivodeship & $50 \%$ & & & & & & & & & & & & & & & & & \\
\hline podkarpackie voivodeship & $50 \%$ & & & & & & & & & & & & & & & & & \\
\hline podlaskie voivodeship & $50 \%$ & & & & & & & & & & & & & & & & & \\
\hline warmińsko-mazurskie voivodeship & $50 \%$ & & & & & & & & & & & & & & & & & \\
\hline łódzkie voivodeship & $50 \%$ & & & & & & & & & & & $35 \%$ & & & & & & \\
\hline małopolskie voivodeship & $50 \%$ & & & & & & & & & & & $35 \%$ & & & & & & \\
\hline świętokrzyskie voivodeship & $50 \%$ & & & & & & & & & & & $35 \%$ & & & & & & \\
\hline lubuskie voivodeship & $50 \%$ & & & & & & & & & & & $35 \%$ & & & & & & \\
\hline opolskie voivodeship & $50 \%$ & & & & & & & & & & & $35 \%$ & & & & & & \\
\hline kujawsko-pomorskie voivodeship & $50 \%$ & & & & & & & & & & & $35 \%$ & & & & & & \\
\hline mazowieckie voivodeship & $50 \%$ & & & & & & & & $30 \%$ & & & $35 \%$ & & & & & & \\
\hline zachodniopomorskie voivodeship & $50 \%$ & & & & $40 \%$ & & & & & & & $35 \%$ & & & & & & \\
\hline pomorskie voivodeship & $50 \%$ & & & & $40 \%$ & & & & & & & $35 \%$ & & & & & & \\
\hline śląskie voivodeship & $50 \%$ & & & & $40 \%$ & & & & & & & $25 \%$ & & & & & & \\
\hline wielkopolskie voivodeship & $50 \%$ & & & & $40 \%$ & & & & & & & $25 \%$ & & & & & & \\
\hline dolnośląskie voivodeship & $50 \%$ & & & & $40 \%$ & & & & & & & $25 \%$ & & & & & & \\
\hline Warsaw-West subregion & $50 \%$ & & & & & & & & $30 \%$ & & & $20 \%$ & & & & & & \\
\hline City of Krakow & $40 \%$ & & & & $50 \%$ & & & & & & & $35 \%$ & & & & & & \\
\hline Gdansk subregion & $40 \%$ & & & & & & & & & & & $35 \%$ & & & & & & \\
\hline City of Poznan & $40 \%$ & & & & & & & & & & & $25 \%$ & & & & & & \\
\hline City of Wroclaw & $30 \%$ & & & & $40 \%$ & & & & & & & $25 \%$ & & & & & & \\
\hline City of Warsaw & $30 \%$ & & & & & & & & & & & $15 \%$ & & & & $10 \%$ & & \\
\hline
\end{tabular}

Source: the authors 
Table A2. Main changes in SEZ institutional arrangements

\begin{tabular}{|c|c|c|c|}
\hline Period & Maximum financial aid & Territorial limit & Time horizon \\
\hline 1995 & $\begin{array}{l}\text { Total exemption from PIT and/or CIT of income earned } \\
\text { during half the time of SEZ existence (in principle } \\
\text { during } 10 \text { years from the firm start of operations in the } \\
\text { zone), } 50 \% \text { exemption from PIT and/or CIT in the } \\
\text { remainder of operations in the zone. }\end{array}$ & no upper limit & 2015 \\
\hline 1999 & - & limit set at $6325 \mathrm{ha}$ & - \\
\hline 2001 & $\begin{array}{l}\text { The tax exemption limited to the maximum aid } \\
\text { intensity cap set out for each region separately. The } \\
\text { maximum aid caps are expressed as percentages of } \\
\text { costs related to investment or employment (qualified } \\
\text { costs) generated by the firm in the zone. }\end{array}$ & - & - \\
\hline 2004 & $\begin{array}{l}\text { Increase of SEZ available territory for large firms. } \\
\text { From } 1 \text { May } 2004 \text { the maximum aid intensity caps were } \\
\text { set at: } \\
\text { - } \quad 30 \% \text { in the territory of Warsaw and Wrocław } \\
40 \% \text { in the territory of Gdynia, Gdansk, } \\
\text { Sopot, Krakow and Poznań } \\
\text { - } 50 \% \text { in the rest of Poland. }\end{array}$ & limit set at 8000 ha & - \\
\hline 2006 & - & limit set at $12000 \mathrm{ha}$ & - \\
\hline 2007 & $\begin{array}{l}\text { The maximum aid intensity caps set at: } \\
\text { - } 40 \% \text { in zachodniopomorskie, pomorskie, } \\
\text { wielkopolskie, dolnośląskie, śląskie and } \\
\text { mazowieckie (until 2010) voivodeships; } \\
\text { - } 30 \% \text { in Warsaw and mazowieckie } \\
\text { voivodeship (from } 2011 \text { on); } \\
\text { - } 50 \% \text { in the rest of Poland. }\end{array}$ & - & - \\
\hline 2008 & - & limit set at $20000 \mathrm{ha}$ & \\
\hline 2009 & - & - & $\begin{array}{l}\text { all designations } \\
\text { prolonged to } 2020\end{array}$ \\
\hline 2013 & - & - & $\begin{array}{l}\text { all designations } \\
\text { prolonged to } 2026\end{array}$ \\
\hline 2014 & $\begin{array}{l}\text { The maximum aid intensity caps set at: } \\
\text { - } 15 \% \text { in Warsaw (1 July } 2014-31 \text { December } \\
\text { - } 1017 \text { ); } \\
\quad \text { December 2020); } \\
\text { - } 20 \% \text { in Warsaw-West subregion; } \\
\text { - } 25 \% \text { in dolnośląskie, wielkopolskie, śląskie } \\
\text { voivodships; } \\
\text { - } 50 \% \text { in lubelskie, podkarpackie, podlaskie, } \\
\text { warmińsko-mazurskie voivodships; } \\
\quad 35 \% \text { in the rest of Poland. }\end{array}$ & - & - \\
\hline 2015 & - & limit set at $25000 \mathrm{ha}$ & - \\
\hline 2018 & - & upper limit removed & $\begin{array}{l}\text { SEZ designations } \\
\text { granted for } 10 \text { to } 15 \\
\text { years }\end{array}$ \\
\hline
\end{tabular}

Source: the authors 
Figure A3. Number of counties by SEZ-hosting status

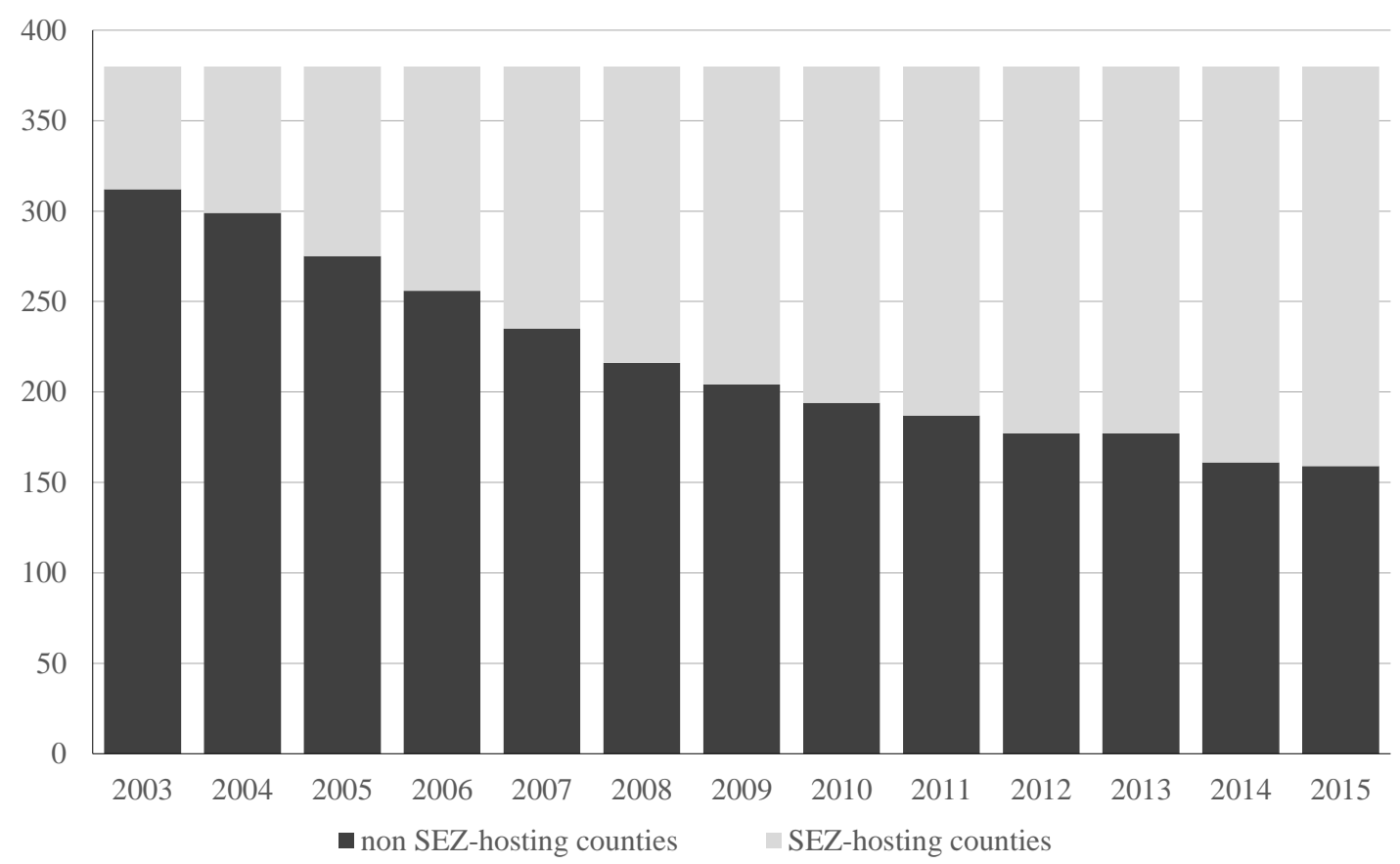

Source: the authors

Figure A4. SEZ-based capital investment by year

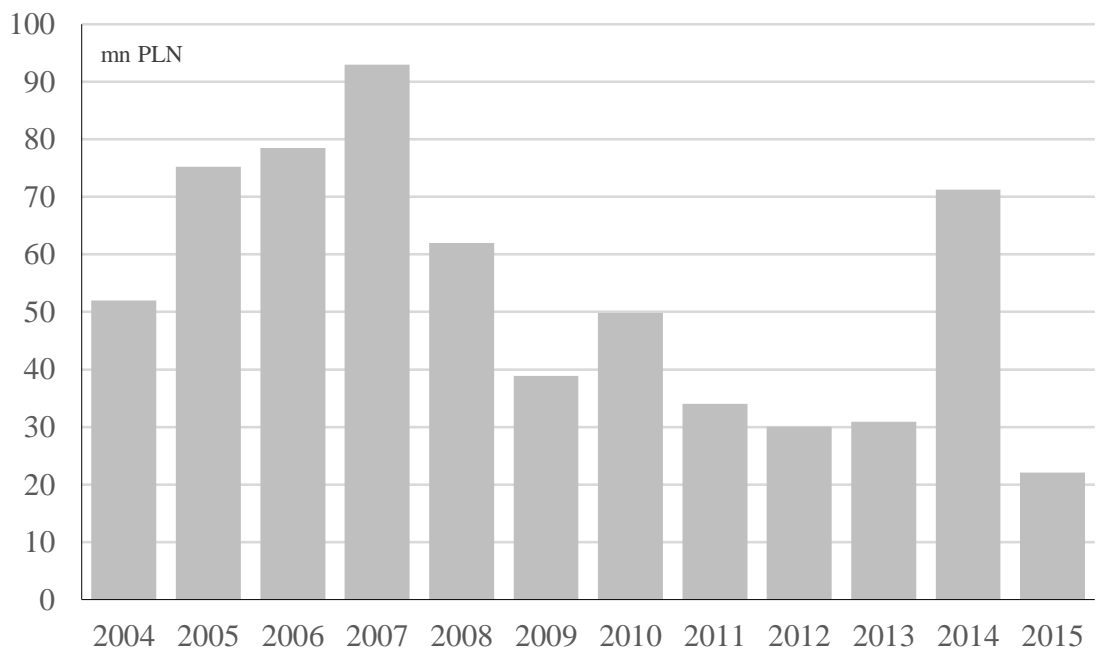

Source: the authors 


\begin{tabular}{|c|c|c|c|c|c|c|c|c|c|c|c|c|}
\hline & & $\begin{array}{l}\text { total } \\
\text { counties }\end{array}$ & $\begin{array}{l}\text { SEZ non- } \\
\text { hosting } \\
\text { counties }\end{array}$ & $\begin{array}{c}\text { SEZ- } \\
\text { hosting } \\
\text { counties }\end{array}$ & $\begin{array}{l}\text { SEZ-hosting } \\
\text { counties, } \\
\text { below average } \\
\text { e in both } \\
\text { investment and } \\
\text { employment } \\
\text { growth }\end{array}$ & $\begin{array}{l}\text { SEZ-hosting } \\
\text { counties, } \\
\text { above } \\
\text { average in } \\
\text { investment } \\
\text { growth }\end{array}$ & $\begin{array}{l}\text { SEZ-hosting } \\
\text { counties, } \\
\text { above average } \\
\text { in employment } \\
\text { growth }\end{array}$ & $\begin{array}{l}\text { SEZ-hosting } \\
\text { couties, above } \\
\text { average in both } \\
\text { investment and } \\
\text { employment } \\
\text { growth }\end{array}$ & $\begin{array}{l}\text { SEZ-hosting } \\
\text { counties, } \\
\text { above average } \\
\text { in investment } \\
\text { growth and } \\
\text { below average } \\
\text { in employment } \\
\text { growth }\end{array}$ & $\begin{array}{c}\text { SEZ-hosting } \\
\text { counties, } \\
\text { above average } \\
\text { in employment } \\
\text { growth and } \\
\text { below average } \\
\text { in investment } \\
\text { growth }\end{array}$ & $\begin{array}{c}\text { difference } \\
\text { between } 4 . \\
\text { and } 7 .\end{array}$ & t-statistic \\
\hline & & (1) & (2) & (3) & (4) & (5) & (6) & (7) & $(8)$ & (9) & (10) & (11) \\
\hline $\mathrm{n}($ counties $\times$ years $)$ & - & 4927 & 2847 & 2080 & 1362 & 563 & 624 & 469 & 94 & 155 & - & \\
\hline number of SEZ-based companies (companies $\times$ years) & - & 13768 & 0 & 13768 & 6168 & 6868 & 7173 & 6441 & 427 & 732 & - & \\
\hline number of municipal counties (counties $\times$ years) & - & 845 & 429 & 416 & 172 & 193 & 210 & 159 & 34 & 51 & - & \\
\hline share of municipal counties (counties $\times$ years) & - & $17 \%$ & $15 \%$ & $20 \%$ & $13 \%$ & $34 \%$ & $34 \%$ & $34 \%$ & $36 \%$ & $33 \%$ & -21 p.p. & \\
\hline share of rural area & - & $51 \%$ & $53 \%$ & $48 \%$ & $49 \%$ & $46 \%$ & $45 \%$ & $47 \%$ & $42 \%$ & $41 \%$ & 2 p.p. & $2.742 * * *$ \\
\hline population density & residents $/ \mathrm{km}^{2}$ & 383 & 345 & 435 & 290 & 706 & 666 & 648 & 993 & 720 & -358 & $-9.2632 * * *$ \\
\hline of companies density & $\begin{array}{l}\text { companies/10t } \\
\text { h residents }\end{array}$ & 1359 & 1311 & 1426 & 1352 & 1550 & 1552 & 1529 & 1658 & 1624 & -177 & $-8.540 * * *$ \\
\hline GFCF & $m \ln P L N$ & 304 & 171 & 486 & 260 & 981 & 677 & 678 & 2491 & 672 & -418 & $-10.373^{* * *}$ \\
\hline share of industry sector & - & $29 \%$ & $27 \%$ & $32 \%$ & $30 \%$ & $37 \%$ & $38 \%$ & $39 \%$ & $31 \%$ & $35 \%$ & -9 p.p. & $-15.949 * * *$ \\
\hline road density & $\mathrm{km} / \mathrm{km}^{2}$ & 107 & 100 & 116 & 101 & 143 & 142 & 138 & 171 & 156 & -37 & $-7.543 * * *$ \\
\hline wages & $\begin{array}{l}\text { \% of country } \\
\text { average }\end{array}$ & $84 \%$ & $83 \%$ & $85 \%$ & $84 \%$ & $89 \%$ & $88 \%$ & $88 \%$ & $94 \%$ & $90 \%$ & -4 p.p. & $-7.482 * * *$ \\
\hline industrial production & PLN/resident & 16418 & 12533 & 22165 & 16783 & 32922 & 32515 & 33221 & 31432 & 30377 & -16438 & $-10.927^{* * * *}$ \\
\hline unemployed & persons & 5681 & 5129 & 6437 & 5479 & 8817 & 8066 & 8677 & 9512 & 6217 & -3199 & $-8.569 * * *$ \\
\hline unemployment rate & - & $17 \%$ & $17 \%$ & $16 \%$ & $17 \%$ & $14 \%$ & $14 \%$ & $14 \%$ & $11 \%$ & $13 \%$ & 2 p.p. & $6.590^{* * * *}$ \\
\hline activity rate & - & $39 \%$ & $39 \%$ & $39 \%$ & $38 \%$ & $41 \%$ & $41 \%$ & $41 \%$ & $42 \%$ & $40 \%$ & -2 p.p. & $-6.570 * * *$ \\
\hline graduates & $\begin{array}{l}\text { persons/10th } \\
\text { residents }\end{array}$ & 27 & 25 & 29 & 21 & 41 & 44 & 40 & 47 & 56 & -19 & $-5.517 * * *$ \\
\hline local government deficit & $\begin{array}{l}\text { government } \\
\text { revenues } \\
\% \text { of local }\end{array}$ & $-2.1 \%$ & $-2.1 \%$ & $-2.2 \%$ & $-2.1 \%$ & $-2.2 \%$ & $-2.3 \%$ & $-2.3 \%$ & $-1.7 \%$ & $-2.5 \%$ & 0.2 p.p. & 0.564 \\
\hline local government investment expenditure & $\begin{array}{l}\text { government } \\
\text { revenues } \\
\% \text { of local }\end{array}$ & $18.1 \%$ & $17.9 \%$ & $18.2 \%$ & $17.9 \%$ & $18.6 \%$ & $19.0 \%$ & $18.9 \%$ & $17.3 \%$ & $19.4 \%$ & -1.0 p.p. & $-2.405^{* *}$ \\
\hline local government social expenditure & $\begin{array}{l}\text { government } \\
\text { revenues }\end{array}$ & $12.5 \%$ & $12.7 \%$ & $12.2 \%$ & $12.8 \%$ & $11.0 \%$ & $11.3 \%$ & $11.3 \%$ & $9.4 \%$ & $11.3 \%$ & 1.5 p.p. & $7.553 * * *$ \\
\hline net enrollment rate in vocational training & - & $46 \%$ & $46 \%$ & $46 \%$ & $46 \%$ & $45 \%$ & $46 \%$ & $46 \%$ & $44 \%$ & $46 \%$ & 1 p.p. & $1.693 *$ \\
\hline wage fund & $m \ln P L N$ & 109 & 73 & 159 & 95 & 287 & 216 & 205 & 699 & 251 & -110 & $-8.0536 * * *$ \\
\hline share of foreign capital in SEZ-based companies & - & $50 \%$ & -- & $50 \%$ & $37 \%$ & $79 \%$ & $75 \%$ & $77 \%$ & $85 \%$ & $69 \%$ & -41 p.p. & $-22.743 * * *$ \\
\hline $\begin{array}{l}\text { share of high- and medium-high tech companies in } \\
\text { SEZ-based fixed assets }\end{array}$ & - & $32 \%$ & -- & $31 \%$ & $25 \%$ & $44 \%$ & $44 \%$ & $44 \%$ & $42 \%$ & $42 \%$ & -20 p.p. & $-10.484 * * *$ \\
\hline $\begin{array}{l}\text { share of low- and medium-low tech companies in } \\
\text { SEZ-based fixed assets }\end{array}$ & & $63 \%$ & -- & $63 \%$ & $70 \%$ & $50 \%$ & $50 \%$ & $50 \%$ & $54 \%$ & $50 \%$ & 20 p.p. & $10.620 * * *$ \\
\hline maximum intensity of regional aid & - & $44 \%$ & -- & $44 \%$ & $44 \%$ & $43 \%$ & $43 \%$ & $43 \%$ & $42 \%$ & $42 \%$ & $1 \%$ & $2.003 * *$ \\
\hline
\end{tabular}

Source: the authors based on Ministry of Economy data. Notes: column 11 contains the $t$-statistics in tests for equality of means. Stars denote statistical significance of the difference at $1 \%(* * *), 5 \%(* *)$ and $10 \%(*)$ significance level. 
Table A6. SEZ-based firms' employment and investment distribution statistics

\begin{tabular}{ccccccccc}
\hline \hline & \multicolumn{4}{c}{ Investment } & & \multicolumn{3}{c}{ Employment } \\
$\mathbf{2 0 0 3}$ & $34,577,676$ & 392,740 & 737,400 & $16,151,100$ & 152 & 51 & 16 & 133 \\
$\mathbf{2 0 0 4}$ & $38,687,539$ & $5,182,837$ & $1,326,268$ & $21,354,634$ & 159 & 51 & 17 & 135 \\
$\mathbf{2 0 0 5}$ & $42,551,460$ & $6,225,500$ & $1,517,750$ & $24,365,500$ & 183 & 54 & 16 & 155 \\
$\mathbf{2 0 0 6}$ & $48,800,759$ & $7,510,000$ & $1,938,000$ & $31,600,000$ & 200 & 55 & 16 & 177 \\
$\mathbf{2 0 0 7}$ & $52,077,368$ & $9,431,031$ & $2,337,599$ & $36,745,000$ & 207 & 57 & 14 & 185 \\
$\mathbf{2 0 0 8}$ & $55,226,706$ & $11,184,030$ & $2,957,280$ & $41,419,645$ & 206 & 58 & 16 & 185 \\
$\mathbf{2 0 0 9}$ & $59,546,793$ & $12,319,596$ & $3,009,740$ & $45,911,484$ & 186 & 53 & 13 & 166 \\
$\mathbf{2 0 1 0}$ & $60,424,868$ & $12,847,042$ & $3,303,219$ & $46,280,200$ & 186 & 53 & 11 & 178 \\
$\mathbf{2 0 1 1}$ & $59,588,775$ & $13,258,900$ & $3,615,500$ & $45,905,032$ & 188 & 55 & 12 & 188 \\
$\mathbf{2 0 1 2}$ & $61,091,306$ & $15,028,580$ & $4,194,900$ & $49,044,000$ & 177 & 52 & 11 & 169 \\
$\mathbf{2 0 1 3}$ & $63,403,252$ & $15,912,621$ & $4,377,654$ & $50,438,379$ & 179 & 49 & 10 & 170 \\
$\mathbf{2 0 1 4}$ & $58,866,850$ & $14,200,219$ & $3,648,883$ & $46,754,120$ & 171 & 44 & 7 & 156 \\
$\mathbf{2 0 1 5}$ & $59,704,759$ & $15,231,435$ & $4,194,900$ & $48,411,270$ & 167 & 43 & 7 & 160 \\
\hline \hline
\end{tabular}

Source: the authors based on Ministry of Economy data

Table A7 SEZ-hosting counties employment and investment distribution statistics

\begin{tabular}{ccccccccc}
\hline \hline & \multicolumn{4}{c}{ Investment } & \multicolumn{3}{c}{ Employment } \\
$\mathbf{2 0 0 3}$ & $224,754,554$ & $39,073,102$ & 379,440 & $154,998,186$ & 987 & 274 & 43 & 1,236 \\
$\mathbf{2 0 0 4}$ & $253,402,759$ & $49,557,292$ & $2,400,061$ & $213,565,608$ & 1,105 & 331 & 47 & 955 \\
$\mathbf{2 0 0 5}$ & $252,780,951$ & $34,986,817$ & $2,400,000$ & $241,400,000$ & 1,089 & 365 & 42 & 1,401 \\
$\mathbf{2 0 0 6}$ & $298,288,925$ & $60,976,350$ & $10,348,953$ & $313,315,169$ & 1,223 & 341 & 68 & 1,629 \\
$\mathbf{2 0 0 7}$ & $329,180,251$ & $82,110,468$ & $13,901,576$ & $302,364,793$ & 1,307 & 349 & 95 & 1,529 \\
$\mathbf{2 0 0 8}$ & $352,284,637$ & $86,264,000$ & $16,466,393$ & $336,982,826$ & 1,313 & 406 & 87 & 1,618 \\
$\mathbf{2 0 0 9}$ & $387,148,728$ & $95,617,564$ & $19,384,513$ & $341,679,285$ & 1,212 & 387 & 85 & 1,375 \\
$\mathbf{2 0 1 0}$ & $397,224,390$ & $102,488,959$ & $14,582,827$ & $376,510,581$ & 1,224 & 436 & 61 & 1,334 \\
$\mathbf{2 0 1 1}$ & $414,948,919$ & $114,260,600$ & $19,201,314$ & $408,011,147$ & 1,310 & 471 & 69 & 1,457 \\
$\mathbf{2 0 1 2}$ & $427,031,270$ & $101,400,349$ & $22,387,355$ & $399,201,984$ & 1,233 & 429 & 89 & 1,297 \\
$\mathbf{2 0 1 3}$ & $456,561,589$ & $118,951,473$ & $33,567,828$ & $427,523,058$ & 1,309 & 475 & 84 & 1,381 \\
$\mathbf{2 0 1 4}$ & $461,327,843$ & $127,448,425$ & $27,435,100$ & $441,591,451$ & 1,337 & 550 & 103 & 1,446 \\
$\mathbf{2 0 1 5}$ & $496,340,261$ & $159,666,270$ & $37,300,753$ & $501,655,982$ & 1,392 & 620 & 117 & 1,634 \\
\hline \hline
\end{tabular}

Source: the authors based on Ministry of Economy data 
Figure A8. SEZ impact on local economies - a conceptual framework

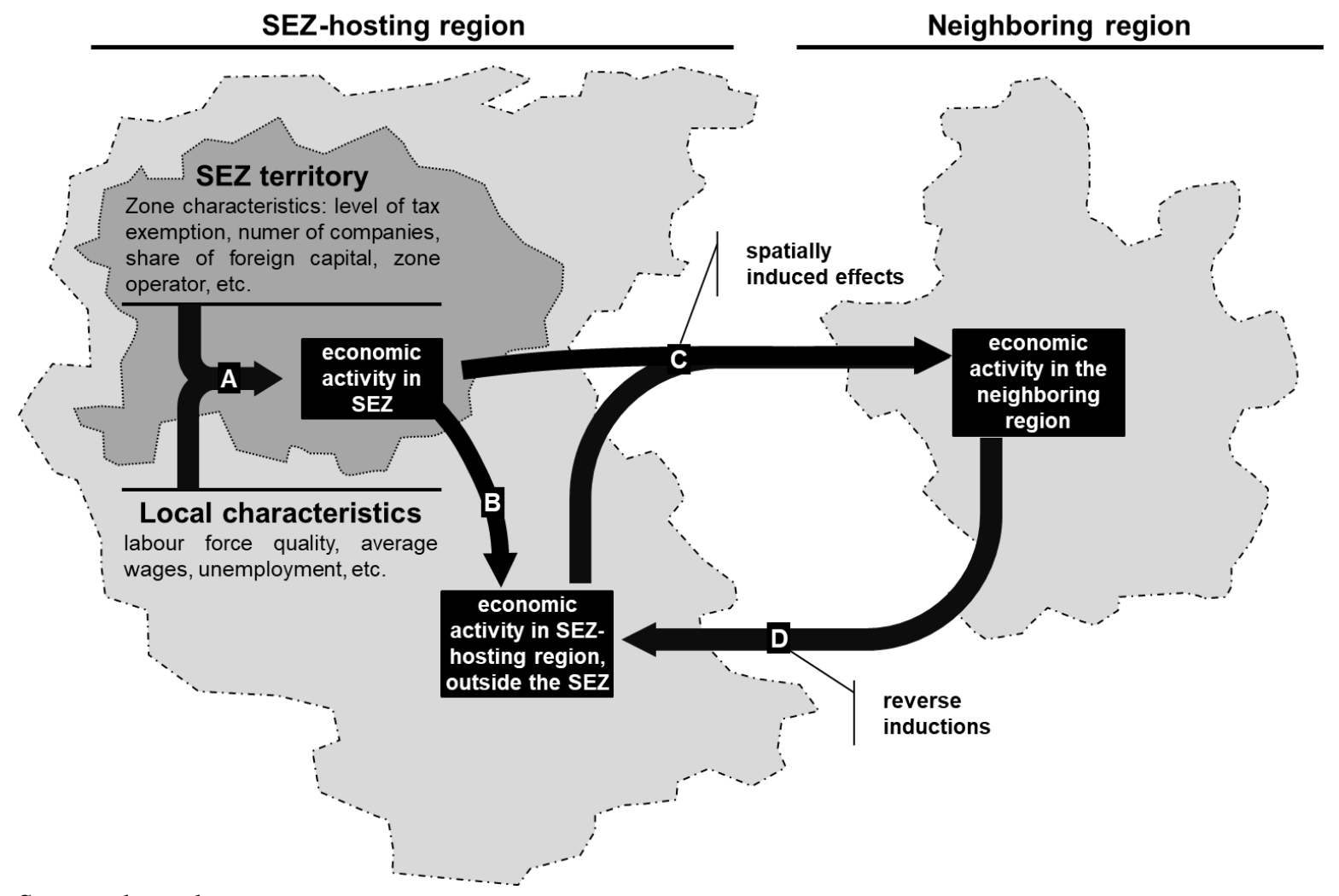

Source: the authors 
Table A9. Estimation results: SEZ management groupings dummy variables

\begin{tabular}{|c|c|c|c|c|c|}
\hline \multirow{5}{*}{ Specification } & Dependent variable: & & & \multirow{5}{*}{ (1) cont. } & \multirow{5}{*}{ (2) cont. } \\
\hline & d_employment & d_investment & & & \\
\hline & Model 9 & Model 10 & & & \\
\hline & $\begin{array}{l}\text { Driscoll-Kraay, SEZ- } \\
\text { management dummies }\end{array}$ & $\begin{array}{l}\text { Driscoll-Kraay, SEZ- } \\
\text { management dummies }\end{array}$ & & & \\
\hline & (1) & (2) & & & \\
\hline wage_av & $\begin{array}{l}56.8381 \\
(0.4377)\end{array}$ & $\begin{array}{l}4.2 \mathrm{e}+07 \\
(1.1233)\end{array}$ & Kam & $\begin{array}{l}46.6485 \\
(1.4669)\end{array}$ & $\begin{array}{l}5.4 \mathrm{e}+06 \\
(0.3271)\end{array}$ \\
\hline wage_fund & $\begin{array}{c}-0.8135 * * * \\
(-3.7994)\end{array}$ & $\begin{array}{c}-1.9 \mathrm{e}+05^{* * *} * \\
(-6.0962)\end{array}$ & Kat & $\begin{array}{l}48.9881 \\
(1.2464)\end{array}$ & $\begin{array}{l}1.6 \mathrm{e}+07 \\
(1.3988)\end{array}$ \\
\hline active & $\begin{array}{c}0.0036 * * * \\
(3.8884)\end{array}$ & $\begin{array}{l}905.6932 * * * \\
(5.3345)\end{array}$ & Kos & $\begin{array}{l}29.5991 \\
(1.0279)\end{array}$ & $\begin{array}{c}-1.8 \mathrm{e}+07 * \\
(-2.0702)\end{array}$ \\
\hline uneployed & $\begin{array}{l}0.0081^{*} \\
(2.0230)\end{array}$ & $\begin{array}{l}1.3 \mathrm{e}+03 \\
(1.6978)\end{array}$ & Krak & $\begin{array}{l}78.5851^{*} \\
(2.1999)\end{array}$ & \\
\hline unemployed_low & $\begin{array}{c}713.1563 * * \\
(2.7775)\end{array}$ & $\begin{array}{c}2.1 \mathrm{e}+08 * * * \\
(4.7069)\end{array}$ & Leg & $\begin{array}{l}13.4352 \\
(0.4539)\end{array}$ & $\begin{array}{c}2.7 \mathrm{e}+07 * * \\
(2.3741)\end{array}$ \\
\hline graduates & $\begin{array}{c}-0.0014 \\
(-0.3566)\end{array}$ & $\begin{array}{l}-2.1 \mathrm{e}+03 \\
(-1.2768)\end{array}$ & Miel & $\begin{array}{l}-33.6517 \\
(-0.4889)\end{array}$ & $\begin{array}{l}-2.3 \mathrm{e}+07 \\
(-1.1293)\end{array}$ \\
\hline ind_production & $\begin{array}{c}0.0017 \\
(1.0647)\end{array}$ & $\begin{array}{l}558.2609 * * \\
(2.2383)\end{array}$ & Pom & $\begin{array}{l}-34.9567 \\
(-0.4417)\end{array}$ & $\begin{array}{l}-2.6 \mathrm{e}+07 \\
(-1.1287)\end{array}$ \\
\hline roads_density & $\begin{array}{c}0.0180 \\
(0.1234)\end{array}$ & $\begin{array}{l}-4.3 \mathrm{e}+04 \\
(-1.3134)\end{array}$ & Słu & $\begin{array}{c}-90.7859 * * \\
(-2.6130)\end{array}$ & $\begin{array}{c}-3.2 \mathrm{e}+07 * * \\
(-2.6448)\end{array}$ \\
\hline border & $\begin{array}{l}-44.6997 \\
(-1.5485)\end{array}$ & $\begin{array}{l}-1.5 \mathrm{e}+07 * \\
(-1.8371)\end{array}$ & Star & $\begin{array}{l}-60.2486 \\
(-1.4135)\end{array}$ & $\begin{array}{l}-1.3 \mathrm{e}+07 \\
(-1.1697)\end{array}$ \\
\hline remaining_years & $\begin{array}{c}23.7743 * * \\
(2.9318)\end{array}$ & $\begin{array}{l}3.1 \mathrm{e}+06 \\
(1.5581)\end{array}$ & Suw & $\begin{array}{l}-56.4356^{*} \\
(-1.9445)\end{array}$ & $\begin{array}{c}-2.3 \mathrm{e}+07 * * \\
(-2.2394)\end{array}$ \\
\hline max_exmpt & $\begin{array}{l}425.7374 * * \\
(2.5922)\end{array}$ & $\begin{array}{l}9.2 \mathrm{e}+07 * \\
(2.1110)\end{array}$ & Tar & $\begin{array}{c}8.3667 \\
(0.0754)\end{array}$ & $\begin{array}{l}8.2 \mathrm{e}+06 \\
(0.6238)\end{array}$ \\
\hline n_SEZ_firms & $\begin{array}{c}1.5886 \\
(0.4055)\end{array}$ & $\begin{array}{l}2.0 \mathrm{e}+06 \\
(1.5249)\end{array}$ & Wat & $\begin{array}{l}59.1642 \\
(1.1132)\end{array}$ & $\begin{array}{c}5.3 \mathrm{e}+07 * * * \\
(3.2211)\end{array}$ \\
\hline share_foreign & $\begin{array}{c}48.4584 * * \\
(2.2595)\end{array}$ & $\begin{array}{c}2.1 \mathrm{e}+07 * * \\
(2.9567)\end{array}$ & War & $\begin{array}{l}-36.6604 \\
(-0.7284)\end{array}$ & $\begin{array}{l}-1.1 \mathrm{e}+07 \\
(-0.7140)\end{array}$ \\
\hline technology & $\begin{array}{c}-2.3219 \\
(-0.0955)\end{array}$ & $\begin{array}{l}1.7 \mathrm{e}+07 * \\
(1.8287)\end{array}$ & Łódz & & $\begin{array}{l}7.9 \mathrm{e}+06 \\
(0.9167)\end{array}$ \\
\hline gini_employment & $\begin{array}{l}96.6802 \\
(1.2077)\end{array}$ & & & & \\
\hline \multirow[t]{2}{*}{ gini_investment } & & $\begin{array}{l}3.1 \mathrm{e}+07 \\
(1.1008)\end{array}$ & & & \\
\hline & & & Constant & $\begin{array}{c}-7.7 \mathrm{e}+02 * * * \\
(-3.1645)\end{array}$ & $\begin{array}{c}-1.9 \mathrm{e}+08 * * * \\
(-3.5073)\end{array}$ \\
\hline $\begin{array}{c}\mathrm{N} \\
N \_g \\
\mathrm{r} 2 \\
\end{array}$ & & & & $\begin{array}{c}1826 \\
235 \\
0.047 \\
\end{array}$ & $\begin{array}{c}1826 \\
235 \\
0.065 \\
\end{array}$ \\
\hline
\end{tabular}

Notes: Table A8. presents models 9 and 10 estimation results on the full sample of SEZ-hosting counties. Dependent variables are the net number of jobs created by firms operating in SEZ $\mathrm{i}$ in the year $\mathrm{t}$ (d_employment, model 9) and net fixed capital formation of these firms (d_investment, model 10). Apart from the explanatory variables included in models 1-6, models 9 and 10 include SEZ grouping-specific dummy variables. Detailed specifications of models 9 and 10 are discussed in Section 5. Variables definitions are reported in Table 4. t-statistics for coefficient estimates are given in parentheses. Stars denote estimates significance at $1 \%(* * *), 5 \%(* *)$ and $10 \%(*)$ levels. 